\title{
European seaweeds under pressure: Consequences for communities and ecosystem functioning
}

\author{
Frédéric Mineur a,b,*, Francisco Arenas ${ }^{c}$, Jorge Assis ${ }^{\mathrm{d}}$, Andrew J. Davies ${ }^{\mathrm{e}}$, Aschwin H. Engelen ${ }^{\mathrm{d}}$, \\ Francisco Fernandes ${ }^{\mathrm{d}}$, Erik-jan Malta ${ }^{\mathrm{f}}$, Thierry Thibaut $^{\mathrm{g}}$, Tu Van Nguyen ${ }^{\mathrm{a}}$, Fátima Vaz-Pinto ${ }^{\mathrm{c}}$, \\ Sofie Vranken ${ }^{\mathrm{a}}$, Ester A. Serrão ${ }^{\mathrm{d}}$, Olivier De Clerck ${ }^{\mathrm{a}}$ \\ a Phycology Research Group, Biology Department, Ghent University, Belgium \\ b School of Biological Sciences, Queen's University of Belfast, UK \\ c Interdisciplinary Centre of Marine and Environmental Research (CIIMAR), Porto, Portugal \\ d Centre of Marine Sciences (CCMAR), University of the Algarve, Faro, Portugal \\ e School of Ocean Sciences, Bangor University, Menai Bridge, UK \\ ${ }^{\mathrm{f}}$ Instituto de Investigación y Formación Agraria y Pesquera (IFAPA), Centro Agua del Pino, Cartaya, Spain \\ ${ }^{g}$ Aix-Marseille University, Mediterranean Institute of Oceanography (MIO), CNRS/INSU, IRD, UM 110, Campus of Luminy, Marseille, France
}

\section{Keywords:}

Macroalgae

Ecosystem Services

Biodiversity

Climate Change

Biological Invasions

Range Shifts

\begin{abstract}
A B S T R A C T
Seaweed assemblages represent the dominant autotrophic biomass in many coastal environments, playing a central structural and functional role in several ecosystems. In Europe, seaweed assemblages are highly diverse systems. The combined seaweed flora of different European regions hold around 1550 species (belonging to nearly 500 genera), with new species continuously uncovered, thanks to the emergence of molecular tools. In this manuscript we review the effects of global and local stressors on European seaweeds, their communities, and ecosystem functioning. Following a brief review on the present knowledge on European seaweed diversity and distribution, and the role of seaweed communities in biodiversity and ecosystem functioning, we discuss the effects of biotic homogenization (invasive species) and global climate change ( shifts in bioclimatic zones and ocean acidification) on the distribution of individual species and their effect on the structure and functioning of seaweed communities. The arrival of new introduced species (that already account for 5-10\% of the European seaweeds) and the regional extirpation of native species resulting from oceans' climate change are creating new diversity scenarios with undetermined functional consequences. Anthropogenic local stressors create additional disruption often altering dramatically assemblage's structure. Hence, we discuss ecosystem level effects of such stressors like harvesting, trampling, habitat modification, overgrazing and eutrophication that impact coastal communities at local scales. Last, we conclude by highlighting significant knowledge gaps that need to be addressed to anticipate the combined effects of global and local stressors on seaweed communities. With physical and biological changes occurring at unexpected pace, marine phycologists should now integrate and join their research efforts to be able to contribute efficiently for the conservation and management of coastal systems.
\end{abstract}

\section{Introduction}

Coastlines harbor some of the most ecologically and socioeconomically significant ecosystems on the planet (Harley et al., 2006). Marine habitats from the intertidal zone to the continental shelf are estimated to provide over $€ 10$ trillion worth of ecosystem goods and services per year, amounting to approximately $43 \%$ of the global total (Costanza et al., 1997). In such coastal systems, particularly on rocky shores, seaweeds are the dominant autotrophic biomass,

\footnotetext{
* Corresponding author at: School of Biological Sciences, Queen's University of Belfast, UK.

E-mail address: f.mineur@qub.ac.uk (F. Mineur).
}

playing a central structural and functional role in several habitats ranging from turfs to kelp forests. Along the Atlantic European coastlines, seaweed biomass is dominated by brown perrenial algae (Phaeophyceae) belonging to the orders Tilopteridales, Laminariales (kelps), and Fucales (wracks). Kelps are usually found in the subtidal and lower intertidal, and have been described as the "trees" of the oceans (Dayton, 1985). Most Fucales, communally referred to as wracks, are found in the intertidal zone, and although they are usually smaller than kelps (e.g. Fucus spp., Ascophyllum nodosum, Pelvetia canaliculata), they can also form large subtidal forests (namely Cystoseira spp.) (Fig. 1). The understorey habitat is made up of turf-forming species that can include a wide range of red (Rhodophyta), green (Ulvophyceae) and other brown seaweeds. Mediterranean shorelines are often characterized by turf forming algal communities, but canopies formed by a 

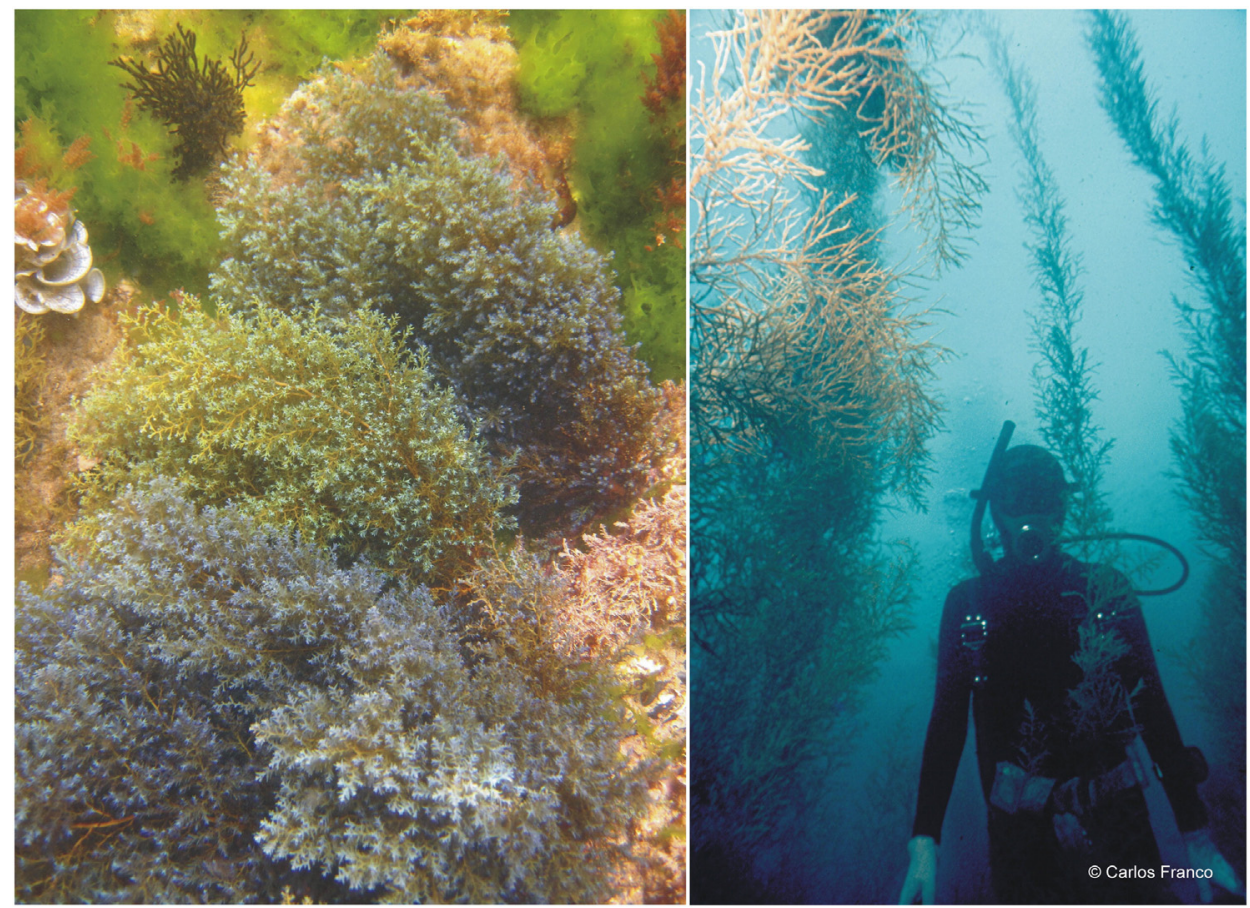

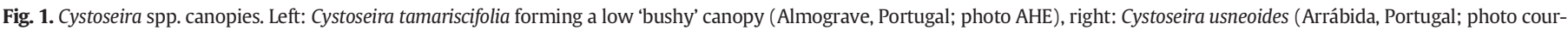
tesy of Carlos Franco).

range of Cystoseira species can dominate the littoral fringe to the lower sublittoral zone (e.g. Ballesteros, 1990; Feldmann, 1937; Giaccone et al., 1994). These different communities are important for coastal ecosystems as they can support high biodiversity through structuring complex habitats for associated species, that range from vertebrate predators (Araujo et al., 2013; Steneck et al., 2002) to infaunal communities (Thrush et al., 2011). Seaweeds are widely recognized as autogenic "ecosystem engineers" (Jones et al., 1994) or "foundation species" (Dayton, 1975). Changes in the composition of seaweed communities, either through habitat loss or climate change, will resonate through entire coastal ecosystems.

Anthropogenic activities on coastal areas, such as fishing, tourism, maritime traffic, or exploitation of natural resources, create increasing anthropogenic stress. One third of the world's population live in coastal areas that account for approximately $4 \%$ of Earth's total land area (UNEP, 2006). Europe in particular has a densely populated coastline, which is highly impacted by human activities (EEA, 2006). Marine ecosystems surrounding Europe are among the most threatened by human impacts (Halpern et al., 2008). The most important direct drivers of change in coastal ecosystems, and marine biodiversity loss in particular, are believed to be habitat destruction, overexploitation of resources (e.g. fisheries), pollution, increases in sedimentation, climate change, and invasive species (Claudet and Fraschetti, 2010; Munday et al., 2013; Walker and Kendrick, 1998). Changes in the average and extreme values of air and sea surface temperatures, due to increasing greenhouse gases in the atmosphere, have a pronounced impact on marine organisms and ultimately on the composition of coastal communities (Wernberg et al., 2011a,b). Species that become invasive also impact ecosystems, and are second only to habitat loss as a cause of species endangerment and extinction (Wilcove et al., 1998). European coasts, with nearly a thousand recorded marine alien species (Daisie, 2014; Galil et al. 2014), are highly exposed to that threat.

Seaweeds are affected by both global and local stressors (sensu Brown et al., 2013) (Fig. 2). Global stressors result from human activities or natural fluctuations, that occur on a worldwide level. Although they will have local impacts, they cannot be halted by local action. Earth's orbital eccentricity has an impact on global temperature over periods of thousands of years (Hays et al., 1976). On a shorter (and contemporary) scale (i.e. since the industrial revolution), global warming is mostly triggered by greenhouse gas emissions (mostly originating from human activities), which are also leading to ocean acidification. Disruption of weather patterns due to global warming will also have an impact on coastal areas with more frequent and stronger storm events. These stressors, that have complex interactions, are gathered here under the umbrella of "climate change", in which we also included ocean acidification. The other major global stressor is a process called "biotic homogenization" (McKinney and Lockwood, 1999), that results from humanmediated transport and introduction of living organisms outside their native range, with biological invasions as local impacts. Some local stressors on seaweeds may be direct and evident, such as seaweed harvesting and trampling. Others, such as eutrophication, overgrazing or habitat modification can have either direct or indirect consequences and origins. For instance, eutrophication may have a remote (although local) origin and will trigger a cascade of consequences on coastal ecosystems. Overgrazing is a consequence of changes in the abundance of herbivores and their predators (top-down controls). Habitat modification can also lead to complex consequences, such as increased sedimentation that will ultimately disturb seaweed communities.

This manuscript reviews the effects of the abovementioned stressors on seaweed diversity, their communities and the functioning of the ecosystems that they sustain. This review is mostly focused on the marine biogeographical provinces surrounding Europe, considering both global and local stressors to give an overview of the current knowledge of seaweed diversity of European coastlines and how they are affected by human activities.

\section{Seaweed diversity in Europe}

Accurate estimates of the diversity and distribution of species are essential to understand how communities and ecosystems respond to environmental change and to be able to forecast those changes that will influence ecosystem services on which humans depend. Information on macroalgal diversity and taxonomy is primarily available through 


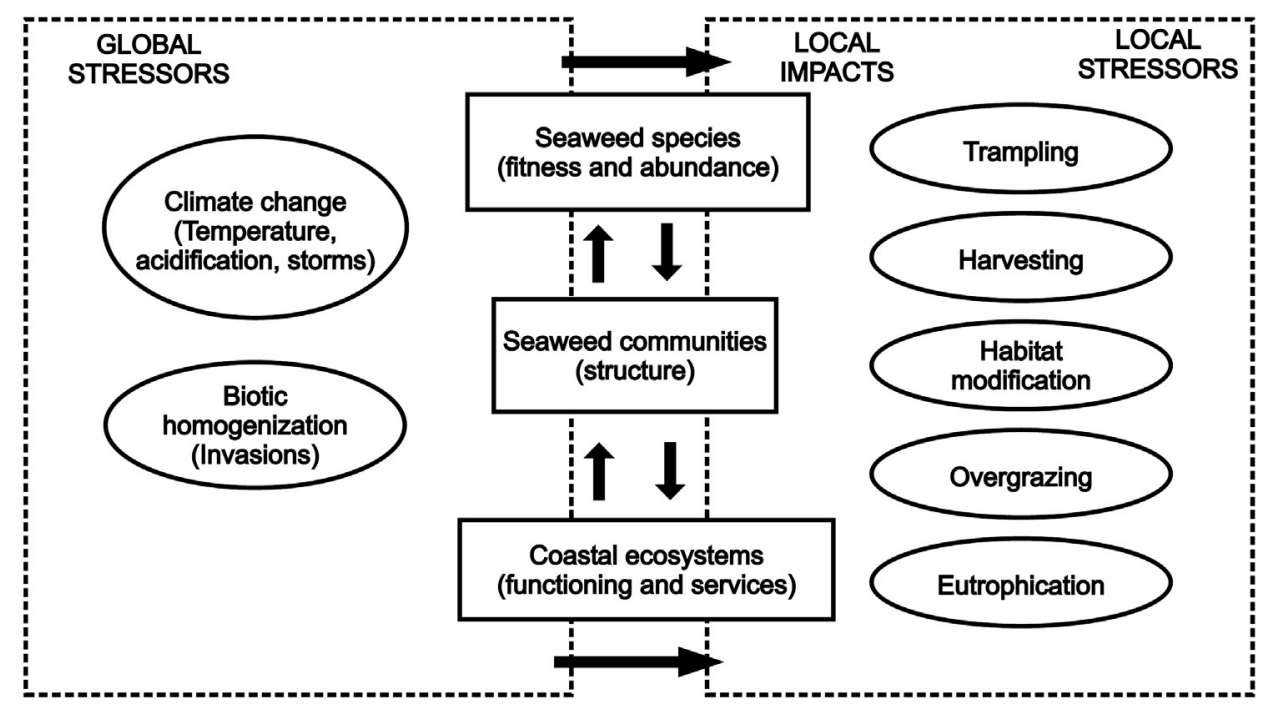

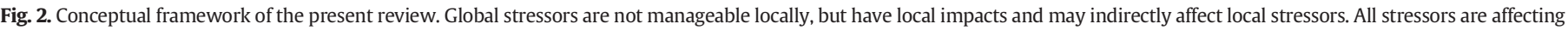

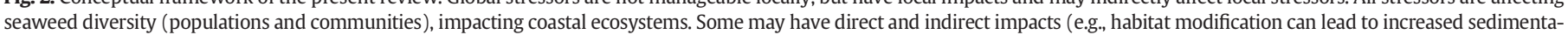
tion and climate change to increased grazing pressure).

the online database AlgaeBase (Guiry and Guiry, 2014), which integrates taxonomic, nomenclatural, bibliographic, and biogeographical information. These data are secondarily integrated in a number of regional or global databases, such as the World Register of Marine Species (WoRMS) (Appeltans et al., 2012; Costello et al., 2013) and the European Ocean Biogeographic Information System (EurOBIS) (Vandepitte et al., 2011). Based on the AlgaeBase data, Guiry (2012) and De Clerck et al. (2013) provided estimates of algal species diversity and discussed temporal trends in the description of new taxa. A major conclusion of both global level studies was that accurate estimates of global algal diversity are especially difficult to establish. Description rates of new algal species show no decline, which is indicative of a large amount of undiscovered species, and even at the genus level, a decline in description rate is not very apparent (De Clerck et al., 2013).

In Europe, the cumulative number of seaweed species described also shows no decline in the rate at which new species are described (Fig. 3). At present approximately 1549 seaweed species are recognized from Europe, classified within 456 genera. The absence of a decline in the rate of species descriptions is not unique to seaweeds. In an analysis of

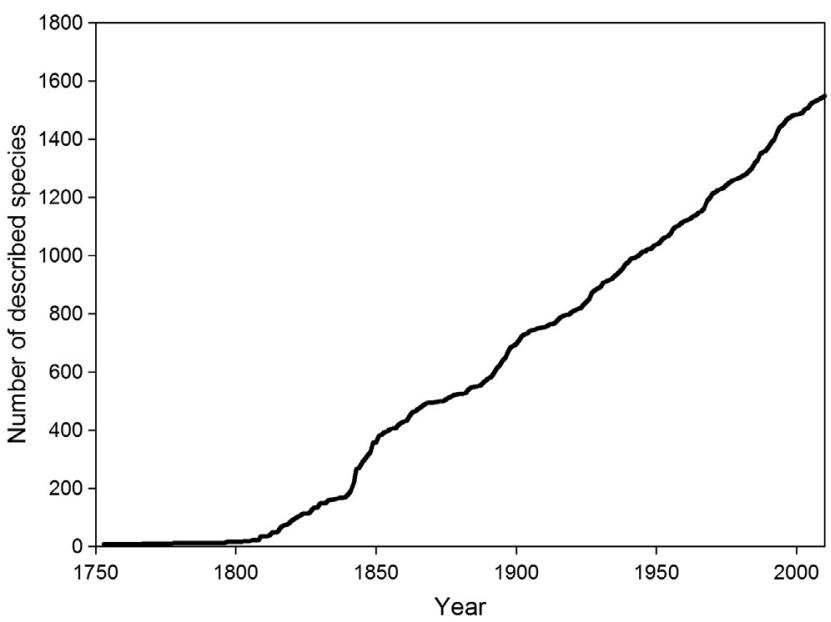

Fig. 3. Temporal accumulation of species and genera on European shores based on the description of the earliest described element for each taxonomic level (Guiry and Guiry, 2014).

Data extracted from Algaebase.
European marine biodiversity, Costello and Wilson (2011) noticed a decrease in the rate of description only for marine birds, mammals and krill. We concur with Costello and Wilson (2011) in that, although previous hyper-estimates of marine species diversity are unlikely to be accurate, significant numbers of species still remain to be described from one of the best-studied and relatively species-poor oceans in the world.

Given that a considerable fraction of seaweed species may still have yet to be described, it is tempting to speculate where these missing species live and what they look like (see Scheffers et al., 2012). From a morphological perspective, most new or reinstated species can be categorized as cryptic or pseudocryptic. Where convergent morphological evolution, morphological stasis, phenotypic plasticity and polymorphism, all common phenomena in seaweed, previously hampered species delimitation, the use of molecular markers has enabled phycologists to better interpret species diversity and more accurately delimit species (Cianciola et al., 2010; Leliaert et al., 2014). Although morphological diagnostic characters may not always be obvious among these new species, we are not necessarily dealing with small and insignificant species. Perhaps the most iconic example is presented by Fucus, a genus of large brown algae that dominates the rocky intertidal of Atlantic shores from southern Portugal to northern Scandinavia. In the last decade alone, no less than two species (Fucus radicans and Fucus guiryi) out of a total of seven were described from European shores (Bergstrom et al., 2005; Canovas et al., 2011; Zardi et al., 2011). However, only in a minority of cases have newly described species also been newly discovered species (i.e. they were known to exits but were included in wider specific entities). Difficulties in distinguishing morphological plasticity from fixed diagnostic traits that separate the various species in the absence of molecular sequence data have resulted in an underestimation of species diversity (e.g. Brodie et al., 2007; Saunders and Lehmkuhl, 2005). There is a clear tendency for these refined species boundaries to result in smaller geographic ranges and many newly described European species are therefore also located in peripheral regions such as Macaronesia (e.g. Afonso-Carrillo et al., 2006; Tronholm et al., 2012, 2013). A recurring example is presented by species that were traditionally recorded from Atlantic as well as Mediterranean coasts but for which gene sequence data provide evidence that the Atlantic and Mediterranean populations are distinct species (e.g. Grateloupia filicina-minima, De Clerck et al., 2005).

Obtaining detailed and accurate records for the distributions of seaweed species may be challenging. Indeed, the above-mentioned 
problems with traditional morphological identifications imply that older published distribution records may be inaccurate and such inaccuracies become multiplied in subsequent literature unless critical revisions are made. Even though regional checklists exist for most countries or regions, these lists generally provide an overview of past literature reports rather than a critical interpretation of species records. Furthermore, primary distribution data are generally not integrated in open access repositories with coordinates that allow distribution mapping, such as EurOBIS. The seaweed distribution data of the British Isles (Hardy and Guiry, 2003) are a notable exception.

\section{Functional consequences of seaweed diversity}

\subsection{Seaweed biodiversity in the context of the new ecosystem functioning paradigm}

Over the past two decades, the functional consequences of the global loss of diversity have received considerable attention by researchers. As a result, the topic of biodiversity and ecosystem functioning has now emerged as a major field within ecological research and is considered a new ecological paradigm (Gamfeldt and Hillebrand, 2008; Naeem, 2002). This research area was initially led by terrestrial researchers with experiments focused on plant diversity-productivity relationships and the mechanisms behind them (Tilman, 1999). Marine ecologists lagged slightly behind and focused more on the role of consumer diversity (Gamfeldt and Bracken, 2009). Nevertheless, seaweed assemblages (at least in intertidal zones) are easy to manipulate, thus they are a convenient model system for experiments examining causal links between diversity and functioning. Several authors have performed studies involving seaweeds within the context of biodiversity-ecosystem functioning research measuring processes such as primary production, nutrient uptake, resistance to invasion and stability. These experiments mostly found positive effects of seaweed diversity, irrespective of the response measured: photosynthetic rates (Bruno et al., 2005; Griffin et al., 2009; Middelboe and Binzer, 2004), biomass accumulation (Bruno et al., 2005), nutrient uptake (Bracken and Nielsen, 2004; Bracken and Stachowicz, 2006), invasion resistance (Arenas et al., 2006) and stability (Boyer et al., 2009; Stachowicz et al., 2008). Also, experiments suggested that diversity effects seem to be the strongest when multiple ecosystem functions were considered simultaneously; e.g. both productivity and stability (Boyer et al., 2009) or productivity and nutrient uptake (Bracken and Williams, 2013). Niche differentiation leading to complementary resource use, facilitative interactions among species and species identity effects were identified as underlying mechanisms governing the diversity and productivity of seaweed communities. In short term experiments the species identity appeared to be the dominant effect (Bruno et al., 2006; Griffin et al., 2009), while in longer experiments mechanisms like facilitation and differential use of resources increase in importance (Stachowicz et al., 2008).

In a recent meta-analysis of marine studies, Gamfeldt et al. (2014) unambiguously illustrated that losing species will cause general reductions in ecosystem functions on average (see also Stachowicz et al., 2008; Worm et al., 2006). However, extrapolating results from experiments to real-world is not always straightforward and in the case of seaweeds the extent of primary productivity reduction associated with the current changes on diversity is uncertain. From experiments on terrestrial systems, Hooper et al. (2012) estimated that species loss levels between 21 and $40 \%$ would reduce primary productivity by $5-10 \%$. Scenarios of species loss so intense are improbable in seaweed assemblages. However local random species loss, like those simulated in most of these experiments usually underestimate the effects of declining diversity (Bracken et al., 2008). Thus, to estimate real-world impacts of losing diversity it is necessary to examine not only the differences in the functional performance among species, but also the differential species' susceptibility to become locally or regionally extinct. This susceptibility is likely linked to the tolerance of the species to global and local stressors which are reviewed later in this article.

\subsection{Seaweeds as carbon sink and sources}

Next to their widely recognized function in structuring coastal ecosystems, seaweeds have a relevant role as carbon sinks. Worldwide, marine macroalgae occupy about an area of $6.8 \times 10^{6} \mathrm{~km}^{2}$ (Duarte and Cebrian, 1996). Productivity accounts for a carbon uptake of 0.46 to $2.55 \mathrm{Pg}\left(1 \mathrm{Pg}=10^{12} \mathrm{~kg}\right.$ ) of carbon per year (Okuda, 2008; Duarte and Cebrian, 1996). This is low compared with phytoplankton (45-50 Pg C year ${ }^{-1}$ ) (Falkowski, 2012). However, phytoplanktonic productivity covers a far greater area, with approximately $3.6 \times 10^{8} \mathrm{~km}^{2}$ (Gattuso et al., 1998). Marine macroalgae dominate shallow coastal areas where most of the seafloor lies within the euphotic zone, supporting highly productive benthic communities (Mann, 1973). Some species of brown algae (mostly Fucales and Laminariales) are able to fix more than $1 \mathrm{~kg} \mathrm{C} \mathrm{m}^{-2}$ year ${ }^{-1}$ (Chung et al., 2011). In particular, kelp forests may reach productivities well above $3 \mathrm{~kg} \mathrm{C} \mathrm{m}^{-2}$ year $^{-1}$ (Gao and Mckinley, 1994). The overall standing crop of kelp forests is estimated to be between 0.015 and $0.039 \mathrm{Pg} \mathrm{C}$, but it could be much higher (Reed and Brzezinski, 2009). Seaweed assemblages have higher biomass and larger turnover times (ca. 1 year) than phytoplankton (several days). These turnover rates are, however, much smaller than many terrestrial plants (i.e. several years for perennials). Indeed, relative short life cycles, high productivity, and the fact that seaweeds inhabit highly disturbed environments, increase the turnover rates of seaweed communities notably (Steneck et al., 2002). Thus, seaweed assemblages may act as valuable carbon sinks compared to phytoplankton due to its higher biomass and larger turnover time (ca. 1 year compared to days), but they are not as efficient as terrestrial plants, or as seagrasses (e.g. Pergent et al., 2014), with longer turnover times.

Seaweeds are also good sources of carbon and most of the carbon sequestered by seaweed outflows within one year. Duarte and Cebrian (1996) estimated that seaweed assemblages export most of the produced biomass out of the system ( $40 \%$ biomass), the rest is either quickly consumed by grazers ( $30 \%)$ or decomposed in situ $(\sim 30 \%)$. Exported matter constitutes the macroalgal drift that is deposited onshore in beaches, where it provides a very important marine subsidy to herbivore and decomposer communities from intertidal and supratidal areas (Orr et al., 2005), or is transported into deeper waters where it forms part of a detrital pathway (Bustamante and Branch, 1996). Exported matter occasionally has unexpected effects on terrestrial food webs (Spiller et al., 2010). Macroalgal export is likely to increase in the near future with more frequent storms as a result of global warming, as well as from increased nutrient run-off that fuels seaweed growth and via a reduction in seaweed-eating fish caused by overfishing.

Seaweed beds, particularly those with upright fronds and a large three-dimensional structure provide food and shelter for associated fauna (Schiel and Foster, 1986). Grazers like sea-urchin, isopod and amphipod species live on and potentially feed directly off seaweeds consuming nearly a third of seaweed carbon (Duarte and Cebrian, 1996). Also, seaweed communities are critical for the recruitment and protection of many commercially important fish and shellfish fisheries (Graham, 2004). Besides the direct consumption by grazers, other organisms like filter feeders benefit from seaweed-derived particulate matter. When seaweeds decay, they give off a large amount of organic matter that is physically or biologically degraded and becomes a very nutritious food for marine fauna (Duggins et al., 1989). Isotopic analyses showed that indeed $60-85 \%$ of the food of filter-feeders came from particulate subtidal kelps (Bustamante and Branch, 1996). Kaehler et al. (2000) found that kelp were important constituents of the diets of the entire coastal food web with the exception of zooplankton community which was dependent on allochthonous nano- and picoplankton. 


\section{Global stressors and long term change of seaweed communities}

\subsection{Biotic homogenization}

Introductions of species to new continents and oceans result in systematic homogenization of biota of a region. The problem is very apparent in European seas, as a hot-spot for aquatic introductions with 879 multicellular alien species that have been reported (Galil et al., 2014). The exact role of exotic species in displacing native ones, however, has been largely debated (e.g. Didham et al., 2005; MacDougall and Turkington, 2005). Seaweed introductions may have an effect on recipient communities (e.g. Schaffelke and Hewitt, 2007; see below) by changing the community structure and relative abundances of native species. However, there is no reported case of native species extinction or even regional extirpation due to seaweed introductions. On the other hand, the addition of new species to an indigenous community will logically increase the species diversity (if simplistically measured as the number of species). However, local increase of diversity due to alien introductions goes along with a decrease of the diversity of ecosystems in the global process of biotic homogenization (McKinney and Lockwood, 1999; Olden and Poff, 2004; Smart et al., 2006).

\subsubsection{Non-native seaweeds in Europe}

The number of seaweed introduction events (i.e. primary introductions, meaning the first arrival of a given species) into Europe has been exponentially increasing over the last two centuries (Fig. 4). The description of European seaweed flora, formally initiated by Linnaeus in the 18th century, was mostly undertaken by phycologists during the 19th century (Wynne, 2006). However, it was not until the turn of the 20th century that introduction events were noticed. During this period, there was enthusiasm for the creation of marine laboratories (Conklin, 1988) and naturalists were becoming more familiar with the biological communities present on European shores, introduction events were more noticeable. That was the case for the arrival of species such as Bonnemaisonia hamifera (first observed in 1893) and Colpomenia peregrina (first observed in 1905) that appeared and spread suddenly in the English Channel area (Sauvageau, 1918). Throughout the 20th century, such primary introduction events were more frequently observed, displaying an exponential pattern due to an increase of transport vectors.

For the contemporary period (i.e. from the 20th century), vectors for seaweed introductions were characterized as being mostly maritime traffic and aquaculture activities, as well as various other vectors such as bait and aquarium trade, and scientific research (Hewitt et al.,

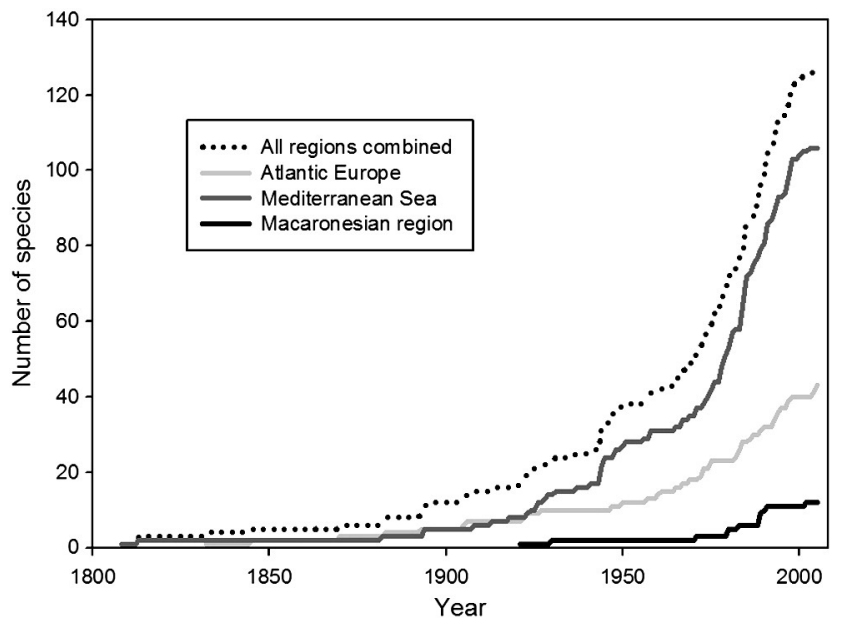

Fig. 4. Cumulative total number of introduced seaweed species observed on Atlantic shores of Europe, the Mediterranean Sea and the Macaronesian region (Azores and Canary Islands), over the last centuries (period 1800-2005).

Data compiled from Mineur et al. (2010a).
2007; Williams and Smith, 2007; Mineur et al., 2012a, 2014). During previous centuries, maritime traffic has certainly been the main active vector for the transport of seaweed species across different bioregions, through hull fouling (Carlton and Hodder, 1995) or ballast stones (Brawley et al., 2009). However, in the periods preceding the first marine flora inventories, such introductions went unnoticed. It is only relatively recently that molecular studies, performed on a larger scale, have confirmed the alien status of several macroalgal species that were introduced into Europe, possibly as early as the 19th century, such as Polysiphonia harveyi (McIvor et al., 2001) and Codium fragile subsp. fragile (Provan et al., 2008), pinpointing the North West Pacific as the native area.

Many seaweed species, usually considered to be native in Europe, such as green algal species of the genus Ulva, commonly responsible for green tides (see below; Section 5.4), or the brown algal species affiliated to the genus Ectocarpus, are ubiquitous in many parts of the world (Guiry and Guiry, 2014). Such cosmopolitan species are usually very tolerant species and are found on many vectors, including contemporary maritime traffic vectors such as ballast water (Flagella et al., 2007) or cargo hulls (Mineur et al., 2007). For those species, the alien or native status may be difficult to demonstrate, due to the ancient character of such introductions, and the likely high connectivity, with bidirectional exchanges, between native and introduced populations. Such species, that are not considered native or introduced are called 'cryptogenic' species (Carlton, 1996).

Alien species may also be difficult to distinguish from native ones when they belong to the same 'species complex', sharing identical features and generally referred to as 'cryptic' species. The arrival of such entities may be referred to as cryptic introductions. For instance, Fredericqia deveauniensis, a recently described red alga that was previously confused with Gymnogongrus crenulatus and Ahnfeltiopsis devoniensis, most likely represents an old trans-Atlantic introduction. Interestingly, uncertainty remains regarding the native area of the species, being either the western or eastern Atlantic Ocean (Maggs et al., 2013). Another example is Porphyra olivii which was originally described as a new cryptic species from the Mediterranean Sea (Brodie et al., 2007), but which turned out to be conspecific with an Asian species currently known as Pyropia koreana (Verges et al., 2013). The development of molecular markers over the last 10 years has resulted in DNA barcoding approaches being used as a routine tool to complement morphological identifications during surveys and censuses (e.g. Bertuccio et al., 2011; Manghisi et al., 2010). Other alien red algae (Mineur et al., 2012b; Wolf et al., 2011), including many Halymeniales (De Clerck et al., 2005; Gavio and Fredericq, 2002; Mineur et al., 2010b; Verlaque et al., 2005), as well as brown seaweeds (Verlaque et al., 2009) from the Northwestern Pacific were detected in Europe through such approach. Those observations were always made in the direct vicinity of active shellfish farming facilities. Maritime traffic is mentioned, although not clearly demonstrated, for the arrival of Grateloupia imbricata, found on rocky shores and aquaculture net cages (another potential vector) in the Canary Islands (Garcia-Jimenez et al., 2008). DNA barcoding approaches have also led to the detection of Polysiphonia schneideri, an alien species of western tropical Atlantic origin, on aquaculture and other floating structures in the South of Spain (Diaz-Tapia et al., 2013). Such cases, however, probably represent only a fraction of an extensive list, the true dimensions of which will only become known once we establish a global biogeographic framework of seaweed distributions linked to sequence information which facilitates identification and comparison.

In Europe and the Mediterranean Sea, more than 125 species of seaweeds are considered to have been introduced. The large majority of introductions occurred after the mid-20th century. Many species have been observed only a few times, with a very restricted distribution, while more than 54 species have been spreading more or less extensively (Mineur et al., 2010a). These 54 species therefore fall into the category of "invasive" species (Colautti and MacIsaac, 2004). 


\subsubsection{Origins and hotspots of introductions}

Three pathways and sources can be roughly identified in terms of seaweed introductions. The first pathway triggers arrivals of Red Sea species to the Mediterranean Sea, through the Suez Canal, in a process called "Lessepsian migration" (Por, 1971) or "Erythrean invasion" (Galil, 2006). Such arrivals include species only observed in the Levantine Basin (e.g. Caulerpa mexicana and Caulerpa scalpelliformis, Neomeris annulata, Rhodymenia erythraea) (Aleem, 1948; Bitar et al., 2005; Rayss, 1941). Some species have spread further to the entire Eastern Mediterranean where they have become invasive (e.g. Stypopodium schimperi) (Verlaque and Boudouresque, 1991). In the Mediterranean Sea, there is also a second pool of introduced species that have an Australasian origin, as demonstrated for most of these cases through the advances of molecular phylogeography. Despite a relatively low importance in terms of species number, this pool includes some highly invasive species such as Asparagopsis armata, Asparagopsis taxiformis ("sandfordiana" strain) (Andreakis et al., 2007; Dijoux et al., 2014), Caulerpa cylindracea (Verbruggen et al., 2013; Verlaque et al., 2003), and Caulerpa taxifolia (Jousson et al., 2000). Although not demonstrated through molecular studies, the red filamentous algae Acrothamnion preissii and Womersleyella setacea, two other invaders introduced in the Mediterranean Sea (Boudouresque and Verlaque, 2002; Piazzi and Cinelli, 2001), are native from the same biogeographical zone (Australasia and Central Pacific) (Guiry and Guiry, 2014). Except for C. taxifolia that has been shown to be introduced by the aquarium trade (Jousson et al., 1998), pathways and vectors for other species of this group have never been demonstrated.

Atlantic shores of Europe, as well as Mediterranean lagoons, are usually colonized by introduced seaweeds species with colder affinities than those in the Mediterranean Sea. These species are mostly originating from the North Western Pacific (Japanese archipelago and surrounding regions). The two best known representative of this third pool of species are the Japanese wireweed Sargassum muticum and the Japanese kelp Undaria pinnatifida that were introduced during the 1970s, along with Crassostrea gigas oyster imports. Both species are now widespread, with $S$. muticum present from Norway (Rueness, 1989) to the Atlantic shores of Morocco (Sabour et al., 2013), and U. pinnatifida from Northern Ireland (Minchin and Nunn, 2014) to northern Portugal (Santiago Caamaño et al., 1990). These two species are also found in different coastal lagoons of the Western Mediterranean Sea (Cecere et al., 2000; Curiel et al., 1998; Pérez et al., 1981). One coastal lagoon on the French Mediterranean coasts, the Thau Lagoon, has received attention as a "hotspot" for introduced species of North Western Pacific origin (Verlaque, 2001).

The high proportion of alien macroalgal species ( $32 \%$ of the species) in the Thau lagoon (Boudouresque et al., 2011) can be explained by a number of conditions that would promote the establishment of alien seaweed species: (1) low native diversity due to the low occurrence of natural hard substrata, and (2) relatively recent construction of hard substrata for oyster farming purposes, concomitant with oyster imports from the NW Pacific since the 1970s. This is the case for numerous other coastal lagoons that are more or less enclosed, that offer different physico-chemical conditions from the neighboring open sea, and that are used for numerous human activities, including shellfish farming. Although a particular and localized phenomenon, such "orientalization" of seaweed communities (with species originating from East Asia) is likely to take place on a more extended geographical range during the next few decades, especially on European Atlantic shores, with the spread of species that are already introduced.

The exponential trend of new alien seaweed introductions in Europe is likely to continue for several decades due to several reasons. In the ongoing process of worldwide biotic homogenization, European marine provinces seem to act more as recipient than as donor areas. Lessepsian migrations tend to be unidirectional, from the Red Sea to the Mediterranean Sea, due to a "shortage" of thermophilic species in the Levantine Basin (Boudouresque, 1999; Vermeij, 2012). On the Atlantic shores and Mediterranean lagoons, a high proportion of seaweeds have been introduced (and likely are still being introduced) through imports of $\mathrm{Pa}$ cific oysters from East Asia, and particularly Japan (Mineur et al., 2014). Although the Japanese marine flora is particularly well known (e.g. Yoshida, 1998), no introduced species of European origin has ever been noticed. Only very few native European seaweeds species are known to have been introduced in other biogeographical provinces, such as the red alga Polysiphonia brodiei, now found in New Zealand, Australia and the West Coast of the USA (ISSG, 2014). Although established since probably two centuries, Fucus serratus has only recently been recognized to have been introduced into the Atlantic coast of North America with maritime traffic (i.e. ballast stones) from the British Isles (Brawley et al., 2009) rather than as a natural range expansion.

The exponential trend of seaweed introductions is not likely to be attenuated in the near future. Indeed, a consequence of globalization is the increase in activity and movements of potential vectors from other biogeographical provinces, with primary introductions as a result. On a European scale, spread rates of invasive species have been shown to have been increasing over the course of the last century, accelerating the frequency of secondary introduction events (Mineur et al., 2010a). Also, increasing survey effort involving the use of molecular approaches is facilitating the detection of such species, either newly introduced, or already established. Such studies can be part of early warning systems targeting biological invasions. Although eradication procedures are usually unsuccessful in the marine environment (Olenin et al., 2011), such warning systems may attract attention about active pathways and vectors, and help to prevent further introductions.

\subsubsection{Impacts of seaweed invasions}

Although the introduction of seaweeds outside their native range can be considered as a direct anthropogenic stress, their fate (colonization and spread) into the new environment will be mainly ruled by intrinsic characteristics of the introduced species and the recipient communities. Although most introduced species that become established may have an impact at some level (i.e. "butterfly effect"), most species will remain out of the scope of ecological studies. When a species becomes abundant, in terms of biomass or substrate occupied (i.e. it will have a visual impact and is noticeable), as well as starts to spread, it usually becomes the focus of studies. In Europe, one of the earliest impact of an invasive seaweed that has been observed was the economic damage of $C$. peregrina ("oyster thief") on the French oyster industry at the turn of the 20th century (Sauvageau, 1918). During the following decades, most scientific accounts referred to the invasion chronology and the phenology of introduced species along European shores ("autecology" or "species ecology" sensu Odum, 1959). For instance, Elton (1958) dedicated a section of his book on the ecology of invasions to the spread of $A$. armata tetrasporophyte (=Falkenbergia rufolanosa) in Europe. The arrival of S. muticum in the 1970s (Farnham et al., 1973) triggered numerous field studies (Critchley et al., 1990), due to the justified fears that it would replace native species. Most of these studies focused on the abundances, recruitment and growing performances (e.g. Norton, 1977, 1981), but also, included impact on the recipient communities, as new substratum for epibionts (Withers et al., 1975).

In a review on the impacts of introduced species, Schaffelke and Hewitt (2007) underlined the low number of species that case studies have focused on. Generally, one of the most predominant impacts observed was high biomasses and abundances, resulting in space monopolization, which impact native species in a negative sense. On the Atlantic shores of Europe, this has been shown for S. muticum, competing with other perennial canopy algae such as Laminaria digitata (Cosson, 1999). This species also has been shown to shade native seaweed assemblages underneath which prevents their growth and the success of native recruits, both in Europe and on the west coast of North America where it has also been introduced (Ambrose and Nelson, 1982; De Wreede, 1983; Fernandez, 1999; Valentine et al., 
2007). The seasonal gametophyte of $U$. pinnatifida forms a large thallus with a strong visual impact, present in kelp beds in subtidal areas and lower intertidal in the Atlantic (Castric-Fey et al., 1999). It can also become dominant on substrata usually covered by smaller canopies, such as in the Mediterranean lagoons. In the Venice Lagoon, a complete (100\%) cover by $U$. pinnatifida was shown to cause a decrease in the diversity of the understorey community structure. However, no difference was observed in the species composition (Curiel et al., 1998). Similarly, the Pacific red alga Heterosiphonia japonica, although very abundant, has not been shown to be responsible of any shifts in species composition in Norwegian fjords. Although differences were found between the preand post-invasions seaweed communities, those dissimilarities were most likely caused by range shifting of native species (Husa et al., 2008).

In the Mediterranean Sea, the arrival of $C$. taxifolia and $C$. cylindracea has been the focus of numerous studies. Impacts of invasive Caulerpa species on native flora and fauna can be highly variable. C. taxifolia can locally sustain some of the highest seaweed biomass found on Mediterranean shores (Thibaut et al., 2004). Both Caulerpa species produce dense webs of stolons and fronds (Thibaut and Meinesz, 2004; Capiomont et al., 2005) that can homogenize epibenthic communities on any type of substratum (moving sands excepted), and any level of eutrophication (Meinesz et al., 2001; Piazzi et al., 2005). Native macroalgal communities can be highly affected, with a local decrease of species in invaded areas (Piazzi et al., 2001; Balata et al., 2004). However, despite some previous concerns, impacts on Posidonia oceanica beds have been shown to be limited (Ceccherelli et al., 2002; Molenaar et al., 2009). Generally, the concern for introduced seaweeds is directly linked to the adverse impacts they can have on native species, communities and ecosystems. With increasing dominance they will have greater direct and indirect impacts on native seaweed species and communities as well as cascading effects that impact other trophic levels and ecosystem functioning. Although, on the Atlantic shores of Europe, presence of non-native species seems to be correlated with the diversity of native species (Mineur et al., 2008). Interactions between introduced and native seaweeds might not be fundamentally different from competition among natives as they are centered on resources as space, light and nutrients (bottom up processes). As invasive species in general are more opportunistic they can outcompete native species for any of these resources. Natural and or anthropogenic disturbances facilitate this process further. In addition, introduced species can have competitive advantage over native species because of restricted top down control by grazers due to for example higher growth rates, lower palatability, lower nutritional value, higher chemical defense, etc. As some seaweeds are habitat engineers, introduced seaweeds also can have the ability to change their physical environment, such as sedimentation rates and hydrodynamics and, as such, can indirectly impact ecosystems beyond their trophic level.

One of the main philosophical questions is what should be considered a negative/positive impact. Introduced seaweeds that start to dominate a site previously unoccupied by seaweeds will change local conditions and communities but might result in increased species richness and ecosystem services, which could be considered a positive impact. Displacement of a native species by more complex introduced seaweed might also be considered a positive impact. However, any change due to introduced species might simply be considered unnatural and as such undesired and hence negative. Negative impacts are usually highlighted and research is commonly focused on what is thought to be the worst invaders in the most impacted communities/ecosystems. A critical overview of the literature, however, underlines the gap in knowledge we have on the long terms effects of biotic homogenization on seaweed communities and coastal ecosystems.

\subsection{Climate change impacts on seaweed diversity}

Oceans are absorbing both heat and carbon from the atmosphere, alleviating the impacts of global warming in the environment, which modifies fundamental physical and chemical properties of the ocean. These changes are expected to impact marine ecosystem structure and functioning with likely feedbacks on the climate system (Riebesell et al., 2009). Seaweeds are directly affected by ocean warming. Predicting the final effects of ocean warming, however, is challenging not only because of the large direct and indirect effects involved, but also because of the ecological interactions among different species (Behrenfeld, 2011). Temperature will affect physiological processes altering phenology, growth rate and ultimately the fitness of the different species in different ways with population and community level implications that may include catastrophic shifts (Harley et al., 2012). Seaweeds will have to acclimate or adapt to the new environmental conditions (Bellard et al., 2012; Viejo et al., 2011) or to suffer local extirpation, a situation documented with increasing frequency in the literature (e.g., Lima et al., 2007; Wernberg et al., 2011b; Nicastro et al., 2013).

The capacity of seaweeds to tolerate new thermal conditions is also affected by the past history of species, as organisms typically respond to new conditions based on both the physiological and behavioral adaptations acquired through the course of their evolution (Somero, 2012). For instance, warm-acclimated individuals of the kelp Saccharina latissima seem to cope better with environmental change, with increased photosynthetically efficiency at higher temperatures and achieving maximum photosynthetic rates at lower levels of irradiance (Davison, 1991). Similarly, warm-acclimated embryos of Fucus vesiculosus are more prone to survive during periods of thermal stress (Li and Brawley, 2004). The existence of local ecotypes further demonstrates that populations may adapt to new environmental conditions (Breeman and Pakker, 1994). Under certain conditions and given sufficient selective pressures seaweeds may undergo ecological speciation at ecological rather than evolutionary time-scales (e.g., F. radicans; Pereyra et al., 2009). The rate of environmental change, however, may be critical since rapid changes typically produce more detrimental effects as they outpace the ability of individuals to acclimate or populations to adapt (O'Connor et al., 2012). This is supported by evidence showing that range shifts take place abruptly when physiological tipping-points are overreached during extreme warming events (Harley and Paine, 2009; Stuart-Smith et al., 2010).

The glacial and interglacial periods of the Quaternary ( 2.6 Ma to present-time) were particularly important in shaping the biogeography of terrestrial and marine species, including seaweeds along European shores, leading species to expand and contract ranges in response to the contrasting environmental conditions (Provan, 2013). For instance, during the Last Glacial Maximum (LGM; 26-20 ka) (Clark et al., 2009), the colder and drier climate (Bigg et al., 2008; Otto-Bliesner et al., 2006) coupled with the advance of massive continental ice sheets (Peltier, 1994) caused major habitat losses throughout northern shores (Provan and Bennett, 2008). Ranges contracted significantly for most marine species and the northernmost boundaries were set to approximately $50^{\circ} \mathrm{N}$, a latitude where a sharp oceanographic front divided polar from temperate waters (Bigg et al., 2008). Even though dispersion may have occurred to novel suitable habitats (e.g., northern Africa or western Mediterranean basin; Assis et al., 2014; Neiva et al., 2014), many populations became restricted to small and isolated regions of persistence (i.e. glacial refugia; Provan and Bennett, 2008). Besides these newly expanded ranges, species such as Palmaria palmata, $F$. serratus, $F$. vesiculosus, $F$. ceranoides and $P$. canaliculata may have found refugia along southwest Ireland, the western English Channel shores and/or northwest Iberia (e.g. Provan et al., 2005; Hoarau et al., 2007; Coyer et al., 2011; Neiva et al., 2010, 2012, 2014; Assis et al., 2014). In opposition, during interglacial periods, such as the Holocene ( 12 ka to present-time) we are currently experiencing, the warming climate and retreat of ice sheets led populations to expand from periglacial or southern refugia and colonize the northern European shores (Otto-Bliesner et al., 2006; Provan and Bennett, 2008; Assis et al., 2014). 
Currently, the Holocene has further potential to lead northern range shifts (Schuur et al., 2009) and the rapid pace of environmental change may leave little opportunity for adaptation, suggesting that range shifts associated with local extinction are the most likely outcome for most species. Southern range contractions of seaweed and seagrasses have already become evident, resulting in the extinction of southern populations often representing genetically distinct lineages (e.g., Diekmann and Serrao, 2012; Nicastro et al., 2013; Assis et al., 2013). Although genetic differentiation favors local adaptation and therefore persistence, the reduced genetic diversity of such range edge populations might limit evolvability (Pearson et al., 2009). The Iberian Peninsula contains the distribution limits of many species and is particularly vulnerable to range shifts due to the recent warming trend (Lima and Wethey, 2012). This is the likely cause of range contractions of the intertidal F. vesiculosus (Nicastro et al., 2013; Assis et al., 2014), Himanthalia elongata and F. serratus (Duarte et al., 2013; Martinez et al., 2012), P. canaliculata (Neiva et al., 2014) and of the subtidal Saccorhiza polyschides (Assis et al., 2013; Fernandez, 2011) and Laminaria species (Díez et al., 2012; Fernandez, 2011). In the Mediterranean Sea affected by some of the highest warming rates globally and subjected to various heat waves (Belkin, 2009), such regressions have been observed for the Fucales Cystoseira spp., Fucus virsoides and Sargassum spp. However, in those cases, such impacts are difficult to disentangle from overgrazing, eutrophication, pollution or habitat destruction that seem to be also important causes for the loss and local extinctions of those species (e.g. Airoldi et al., 2008; Bianchi et al., 2014; Boudouresque, 2003; Devescovi and Ivesa, 2007; Falace et al., 2010; Fraschetti et al., 2011; Giakoumi et al., 2012; Mačić et al., 2010; Munda, 1993; Templado, 2014; Thibaut et al., 2005, in press) The recent range contraction of S. latissima along the Norwegian shores (Moy and Christie, 2012) or the decline in abundance of L. digitata in Brittany (Davoult et al., 2011) and Normandy (Gevaert et al., 2008) demonstrates that the negative effects of climate change may not be restricted to the lower latitude European shores.

The dispersal ecology of seaweeds may be determinant in the face of climate change (Arribas et al., 2012), particularly for those species with limited dispersal, which may experience local extinctions whenever extreme environmental conditions arise (Parmesan, 2006). Seaweeds in general have limited dispersal (Kinlan and Gaines, 2003), but even if species could dynamically track environmental change, range contractions at lower latitudes would not be offset by expansions towards northern territories. This is because range shifts in such species have involved only the local expansion fronts (Assis et al., 2014; Neiva et al., 2010, 2014), leaving distinct threatened populations at lower latitudes that frequently possess exceptionally high and unique levels of genetic diversity (Assis et al., 2013; Diekmann and Serrao, 2012; Neiva et al., 2012). Thus, despite northern range expansions, as predicted for L. digitata (Raybaud et al., 2013), F. serratus, F. vesiculosus, and A. nodosum (Assis et al., 2014; Jueterbock et al., 2013), the extinction of rear edges may have disproportionately negative implications for the evolvability and conservation of species as a whole (Hampe and Petit, 2005). Furthermore, new settlements predicted at higher latitudes may represent additional threatening outcomes from climate change with unexpected results for the survival, growth and reproduction of prior well established populations (Bertness et al., 1999).

Besides the new thermal gradients created by global warming, other changes will affect seaweed assemblages widely. For example, the increasing extent of anthropogenic $\mathrm{CO}_{2}$ in the ocean will have both physical and biological consequences. Increasing aqueous $\mathrm{CO}_{2}$ concentration reduces ocean $\mathrm{pH}$ and modifies the balance among the different carbon speciation in the water. Biological effects of increasing $\mathrm{CO}_{2}$ will differ among organisms. Ocean acidification may affect seaweeds in different ways. It may have adverse effects on calcifying organisms such as encrusting or articulated corallines, as well as on various calcifying species belonging to various orders of red, green and brown seaweeds (Doney et al., 2009; Nelson, 2009), by reducing their ability to biomineralize or even causing net dissolution. In contrast, ocean acidification may bring benefits to some groups of photosynthetic organisms, particularly those that operate a relatively inefficient $\mathrm{CO}_{2}$ acquisition pathway. However, unlike terrestrial plants, many marine algae have biochemical tools to concentrate $\mathrm{CO}_{2}$ inside their cells, thus higher carbon availability may not have large effects on productivity (Kroeker et al., 2010). As in the case of temperature, interactions between $\mathrm{CO}_{2}$ with other physical driving forces could hinder our abilities to predict impacts. For example, responses of macroalgae to elevated $\mathrm{CO}_{2}$ seem to be highly modified by light intensity (Gao et al., 2012b; Hepburn et al., 2011).

Other physical changes related with climate change will include the increase of extreme events, the rise of sea level and changes in the UV radiation levels (Gao et al., 2012a). All these global changes seems to occur at velocities never predicted before (Burrows et al., 2011) and probably amplify the effects of other stressors like pollution, fishing, and invasions (Halpern et al., 2008). Understanding how all these stressors affect natural communities and ecosystems and the prevalence of synergistic or non-synergistic interactions remains a challenge for researchers (Crain et al., 2008; Richardson et al., 2012). Thus, many of our current predictions from studies of impacts of single climate stressors on seaweed dominated systems under future environmental conditions will probably need re-examination with increasing recognition of interactions and feedbacks among physical and biological factors (Harvey et al., 2013).

Recently, Brodie et al. (2014) predicted large changes in benthic flora of the North Atlantic in Europe resulting from climate change. Kelp forest will disappear in the south coasts of Europe, and maërl habitats will probably also be severely affected. Seagrasses and small turf seaweeds species will probably proliferate. Climate change will also create favorable conditions to invasive species.

\section{Local threats to seaweed diversity}

In addition to the global stressors discussed above, many local anthropogenic stressors are impacting seaweed assemblages on a restricted area. The local stressors reviewed here have a direct effect on seaweed communities, mainly affecting the populations of these organisms. Loss or reduction of canopy forming seaweeds, as a consequence of these stressors, can have direct and indirect effects on benthic communities both on the short and the long term, reflected in biodiversity and abundance reductions, shifts in composition and ecosystem functioning (Estes et al., 1989; Steneck et al., 2002). As canopy forming seaweeds are in general late successional species, when lost they are most often replaced by more opportunistic algae, such as turf or filamentous species, invasive or ephemeral seaweeds such as Ulva spp. or animals such as barnacles (Davies et al., 2007). Many of these have reduced morphological complexity, reducing habitat formation and the modification of physical and biological factors. In addition, these more opportunistic species have a higher turnover rate thereby reducing stability, which can have profound impacts on epiphytic algal communities and higher trophic levels of the food web (Edgar et al., 2004).

\subsection{Trampling}

Anthropogenic activities on rocky intertidal shores in many cases involve disturbance of people moving around for recreational or harvesting purposes. Trampling affects seaweed composition, cover, diversity and biomass and is intensity dependent (Keough and Quinn, 1998; Milazzo et al., 2002; Araujo et al., 2009, 2012). Experimental trampling on European intertidal rocky shore assemblages dominated by A. nodosum in Portugal reduced the cover of this founder species at the higher trampling intensity. In addition, this also caused reductions of $F$. vesiculosus and associated understorey species, facilitating replacement by ephemeral green algae (Araujo et al., 2009). The effects were still detectable after 54 months of recovery (Araujo et al., 2012), stressing the slow pace of late successional canopy forming seaweeds to overcome disturbance. Demographic model approaches based on field data have revealed that the brown foundation seaweeds, like 
A. nodosum, rely for the persistence of their populations mostly on survival of large (fertile) individuals which makes them vulnerable to disturbances that damages or removes exactly these individuals (Aberg, 1992a,b; Engelen and Santos, 2009; Svensson et al., 2009).

\subsection{Seaweed harvesting}

Seaweed harvesting is probably as old as mankind lived on coastlines. In Europe, seaweed harvesting has been dated back to Neolithic times (Mesnildrey et al., 2012). Originally widely used for domestic purposes such as fuel, soil fertilizer, cattle feed, medicine and food, it later served industrial purposes as a resource for "soda ash" to make glass and "potash" for bleaching and later as an iodine source (Mesnildrey et al., 2012). Nowadays seaweeds are mostly harvested for alginates, fertilizers, cosmetics or processed for health food industries (Bixler and Porse, 2011). In Europe, green, red and brown seaweeds are harvested. Kelps are a considerable important source for alginates. Harvesting of these kelps is managed from the point of maximum yield (Arzel, 1998; Frangoudes, 2011), solely using distribution and abundance as the main source for management and frequently ignoring the ecosystem functional role of the stock (Lorentsen et al., 2010; Wernberg et al., 2010). If properly managed, kelp harvesting can be a sustainable industry as kelps have high growth rates and have shown a remarkable recovery ability after removal (either by humans or by natural disturbance). To a large extent this capacity is probably due to the microscopic stages in the life cycle of kelps that seem to provide a short-term 'seedbank' function (Carney and Edwards, 2006; Barradas et al., 2011; Engelen et al., 2011; Pereira et al., 2011; Kinlan et al., 2003). Good management strategies ideally should take into account species-specific traits as kelp species, for example, differ considerably in their life history and industrial value. A sustainable exploitation program will be highly dependent on what can be acceptable in terms of removal amounts, in terms of biomass turnover, but also on the impacts on ecosystem services. Fish recruitment, for instance can be significantly affected by $33 \%$ thinning of Macrocystis pyrifera forests (O'Connor and Anderson, 2010). Genetic implications of seaweed harvesting are largely unknown. A recent review by Valero et al. (2011) showed that intertidal kelp in general were more genetically structured than subtidal populations, a pattern also recognized in nearshore marine invertebrates (Kelly and Palumbi, 2010). This would indicate that management strategies should be different for harvesting of intertidal and subtidal stocks.

With climate change it is projected that various harvestable seaweeds, such as $L$. digitata, will shift their distributions further north (Raybaud et al., 2013). Apart from ecological consequences, it will likely affect seaweed industries relying on those species. Although kelp forest structure is changing in the NE Atlantic with important implications for ecosystem functions, kelp-dominated ecosystems have received too little research attention (Smale et al., 2013).

\subsection{Habitat modification by human constructions}

Coastlines of most European countries are heavily shaped by human made constructions that either facilitate the use of or defend us from the sea, like for example harbors, dikes, breakwaters and artificial beaches. In Europe, this adds up to about $22,000 \mathrm{~km}^{2}$ and about half the coastline between Spain, France and Italy (Airoldi and Beck, 2007). With the current perspective of rising sea levels and increased storm activities (IPCC, 2007) these constructions will be extended and fortified. Hard artificial structures in particular, strongly impact seaweed communities, as these require hard substrate to attach to. In principle this would provide novel opportunities for seaweeds communities. However, descriptive studies have shown differences in communities inhabiting man-made structures relative to nearby natural rocky shores, as these substrates seem to be abundantly colonized by opportunistic blooming and/or nonnative species rather than local foundation seaweeds (Bulleri and Airoldi, 2005; Glasby et al., 2007; Mineur et al., 2012a; Vaselli et al.,
2008; Thibaut et al., in press). Moreover, such artificial substrates could facilitate source populations and stepping stones for opportunistic or even invasive species to spread and enter seaweed communities on natural substrates. The current developments in marine renewable energy infrastructure like offshore wind turbine farms could add considerable opportunities for opportunistic and invasive species enhancing their spread and increasing pressure on nearby natural communities. The marine traffic involved in the construction and maintenance of these artificial substrates may even reinforce the effect of spreading nuisance species. The negative impact of artificial constructions could partly be overcome by integrating ecological knowledge in design and management as highlighted by Airoldi and Bulleri (2011) and Firth et al. (2014).

\subsection{Overgrazing}

Increasing abundances of grazers that are feeding on macroalgae can lead to the loss of dominant habitat forming species. These changes cause shifts in habitat structure, from abundant canopies to alternative states dominated by filamentous and encrusting species, leading to a drastic reduction of any macroalgal biomass ("barren grounds") (Fig. 5) (Filbee-Dexter and Scheibling, 2014; Hereu et al., 2005; Komatsu et al., 2014; Sala et al., 2011; Vergés et al., 2014a). The main category of grazers that are involved in these processes is sea urchins, with populations that can dramatically proliferate through the loss of their predators, such as sparid fishes in the Mediterranean Sea, due to overfishing (Sala et al., 1998). Proliferation of native herbivorous fish can also be blamed for the loss of habitat-forming species (Verlaque, 1990). But some of the most striking examples are another consequence of biotic homogenization and involve the Lessepian invasive herbivorous fish species Siganus luridus and Siganus rivulatus (rabbitfishes), that are depleting Cystoseira forests in the Eastern Mediterranean Sea (Sala et al., 2011; Vergés et al, 2014b). In many case, overgrazing (by sea urchins or fishes) has been reported to be responsible for the massive loss and local extinctions of various Cystoseira and Sargassum species in the Mediterranean Sea (Bianchi et al., 2014; Thibaut et al., 2005; Sala et al., 2011).

\subsection{Eutrophication and green tides}

Eutrophication caused by excessive loads of (in)organic nutrients is one of the major anthropogenic threats to biodiversity and ecosystem functioning in the coastal marine environment worldwide (Rabalais et al., 2009; CBD, 2006). Nutrients giving rise to the eutrophication processes are of anthropogenic origin (Rosenberg, 1985). Until a few

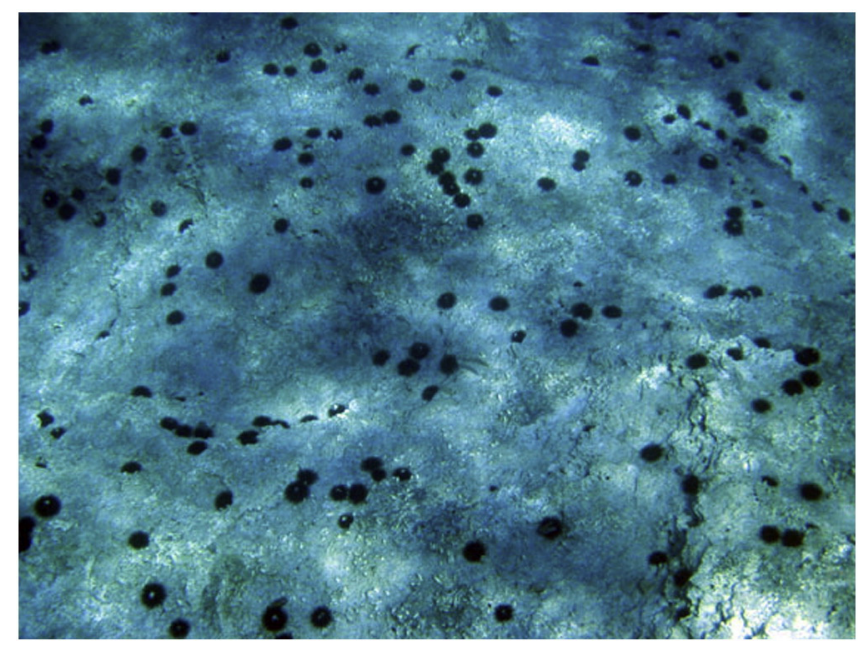

Fig. 5. "Barren ground" induced by the increasing abundance of Arabacia lixula sea urchins, showing the complete disappearance of macroalgal canopies (Bay of Vlora, Albania) (photo TT). 
decades ago urban wastewater discharge was the most important source of nutrients; however with the improvement of wastewater treatment technology (tertiary treatments) and the intensification of agriculture and fertilizer use, diffuse sources and land runoff have been gaining importance in some geographical areas, especially for nitrogen (Artioli et al., 2008; Morand and Merceron, 2005; Valiela et al., 1992). Most nutrients enter through streams or direct runoff although the role of nutrient enriched groundwater seems to increase as well (Stigter et al., 2013; Tournoud et al., 2006). The importance of aquaculture as a nutrient source in Europe is generally modest at the moment, but can be expected to increase considering the growth prospectives of the industry (Aubin et al., 2009; Forrestal et al., 2012).

\subsubsection{Effects on seaweed diversity and community structure}

Eutrophication often goes accompanied by other types of pollution, harmful (micro)algal blooms, introduction of new species (especially in relation to aquaculture) and habitat disturbance. It is therefore not always possible to attribute changes in the macrophyte community to eutrophication alone (Fletcher, 1996). Several common trends, however, have been identified. Nutrient enrichment increases phytoplankton blooms both in intensity and duration and consequently reduces penetration of light in the water column (Duarte, 1995). The development of large floating masses of opportunistic macroalgae is one of the most conspicuous effects of eutrophication (Fletcher, 1996; Morand and Briand, 1996; Valiela et al., 1997). These bloom-forming algae are frequently arranged in thick canopies, whose structure may be shortlasting (i.e. one tidal cycle) (Dion and Le Bozec, 1996) or may persist for weeks or even an entire season, depending on tidal and wave exposure (Malta et al., 2003; Vergara et al., 1998). The most dominant species among the proliferating algae in these mats or blooms, is by far the chlorophyte Ulva, hence the name "green tides" (Fig. 6), although blooms of red (e.g. Ceramium and Gracilaria spp.) (Fletcher, 1996) and brown seaweeds (e.g. Ectocarpus siliculosus, Pilayella littoralis) (Lotze et al., 1999; Thybo-Christesen et al., 1993) have also been observed. A special case might be the so-called "golden tides" caused by the brown alga Sargassum natans that is more likely caused by particular oceanographic processes than eutrophication (Smetacek and Zingone, 2013).

The most spectacular examples of green tides are no doubt the Ulva prolifera blooms that became massive in the Yellow Sea in China since
2007 and seriously disturbed the preparation of the 2008 Olympic sailing competition (Leliaert et al., 2009; Shi and Wang, 2009). Gaining a doubtful fame as the "world's largest macroalgal bloom", it reached a maximum coverage of $4993.9 \mathrm{~km}^{2}$ with an estimated biomass of several million tonnes wet weight (D.Y. Liu et al., 2013). The bloom was facilitated by excess nutrients in the highly eutrophic Yellow Sea in combination with favorable wind and temperature conditions. There is some controversy about its origin however. D.Y. Liu et al. (2013) put the blame unequivocally on the expansion of seaweed (Porphyra) culture, where others (F. Liu et al., 2013; Zhang et al., 2011) stress the importance of fragments in mudflats and aquaculture ponds, which act as propagules seeding bloom events. In Europe, Ulva blooms are best known from Venice Lagoon (Sfriso et al., 1992), Langstone harbor in the UK (Taylor et al., 2001) or the coasts of Brittany (Dion and Le Bozec, 1996). Such blooms, due to eutrophication, have regularly been observed along the European coasts, starting at least since the turn of the 20th century with a first record in the industrialized bay of Belfast Lough (Letts and Richards, 1911). In recent years, blooms observed in Brittany have been linked to the death of dogs, wild boars and a horse, while also suspected of having caused human fatalities, therefore receiving a lot of media attention (e.g. Viscusi, 2011) and leading to considerable damage to the tourist sector.

The increase in biomass of opportunistic macroalgal blooms goes hand in hand with a decline or even complete disappearance of perennial species. In the saline lake the Veerse Meer in the Netherlands, macroalgal species numbers declined from 64 in the early 1950s (den Hartog, 1959) to 48 after its closure from the sea in 1961 (Munda, 1967 ) and to 30 in the early 1990s after decades of progressive eutrophication and artificial tide management (Malta and Verschuure, 1997). Most conspicuous was the decline in brown algal species that all disappeared except for the winter annual Petalonia fascia. Similar relationships between eutrophication and species richness have been reported worldwide (Fletcher, 1996; Middelboe et al., 1998; Raven and Taylor, 2003; Schories et al., 1997; Sfriso et al., 1992; Titlyanov et al., 2011). As for soft bottom systems, green algal blooms have been held responsible for the decline of seagrass stands and associated macroalgae (Hauxwell et al., 2001; Short et al., 1995; Thomsen et al., 2012).

Perhaps even more important than the actual reduction in species number is the reduction in "functional diversity" (Middelboe and Sand-Jensen, 2000; Raven and Taylor, 2003): the qualitative and

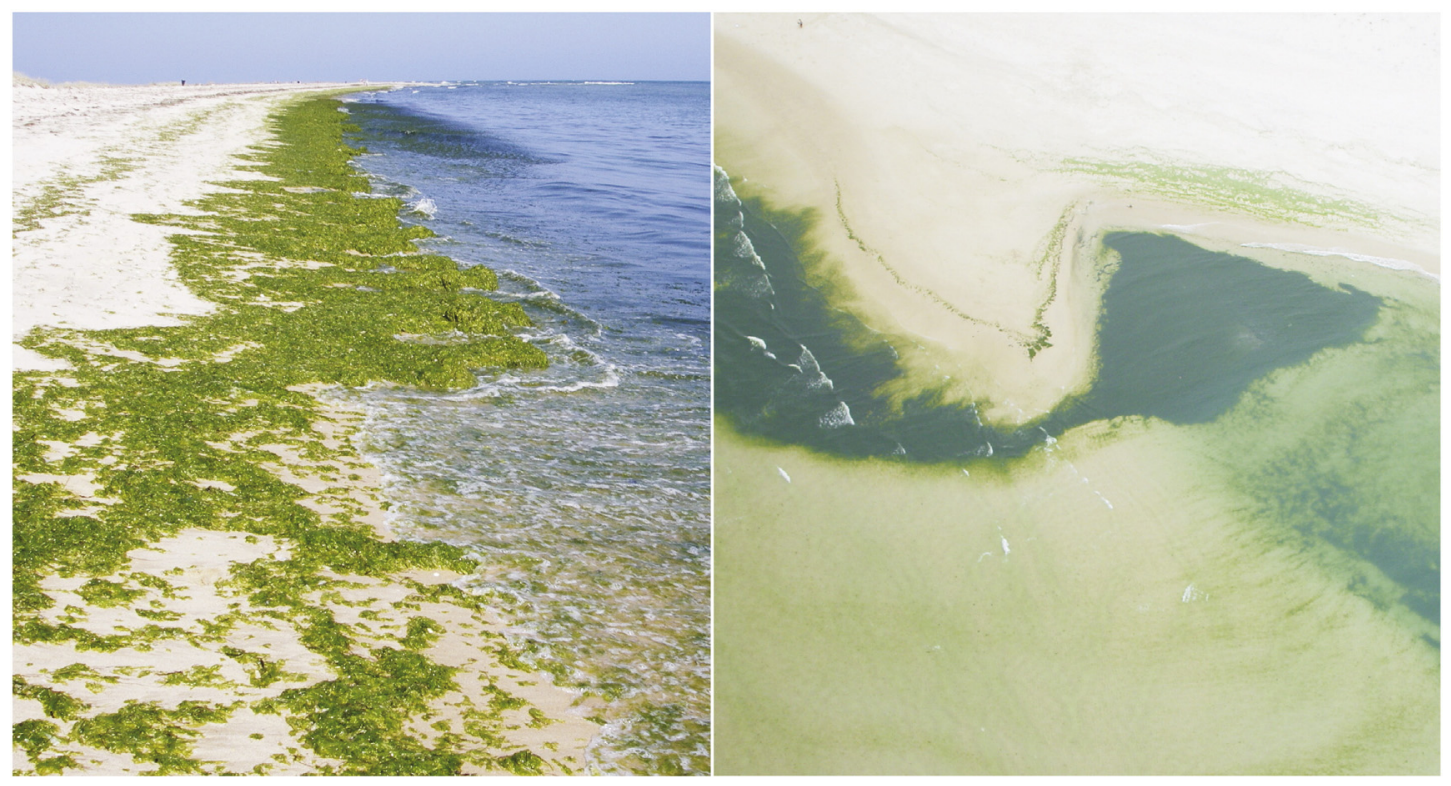

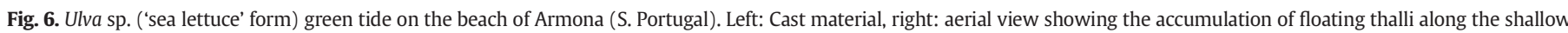
coastal area (photos EM). 
quantitative reduction in the diversity of functional groups caused by the increasing dominance of opportunistic thin foliose or finely branched species over perennial coarsely-branched, thick leathery or coralline species leading to a reduction in the three dimensional complexity of the landscape. Furthermore, the decrease of depth limits of macroalgae and disappearance of characteristic zonation patterns (Breuer and Schramm, 1988; Eriksson et al., 2002; Middelboe and Sand-Jensen, 2000; Middelboe et al., 1998) due to reduced light penetration is an important consequence of eutrophication that has particularly gained attention in the Baltic Sea area.

Fig. 7 shows a generalized model of the effects of eutrophication on macroalgal communities mentioned above (partly adapted from Nienhuis, 1992). The form of the curves is indicative and depends on system specific parameters and conditions. Effects will be increasingly stronger once a certain threshold nutrient loading is crossed (Nienhuis, 1992; Valiela et al., 1997). The exact value of this threshold depends not only on loading but also on water retention time in the systems. Studies by Fox et al. (2012) and Teichberg et al. (2010), indicate that the threshold may be reached by loadings leading to annual mean dissolved inorganic nitrogen concentrations $\leq 10 \mu \mathrm{M}$.

The observed relations between macroalgal diversity and distribution and water quality resulted in the incorporation of macroalgae as a biological quality element (BQE) for the assessment of water quality in European Union member states under the Water Framework Directive (EC, 2000). Monitoring system classifications have been developed based on distribution depth limits, species richness, indicator species and opportunistic algal coverage (EC, 2008). Practical implementation and generalization of these systems however is not without difficulties as can be seen from the multitude of proposed indicator methods and the ongoing scientific debate on the theme (e.g. Ballesteros et al., 2007; Bermejo et al., 2012; Birk et al., 2012; Malta et al., 2011; Neto et al., 2012; Orfanidis et al., 2003; Wilkinson et al., 2007).

\subsubsection{Effects on the ecosystem}

A system dominated by opportunistic algae shows large temporal and spatial variability and is hence inherently instable (Malta and Verschuure, 1997; Malta et al., 2002; Nelson et al., 2003). Blooms are typically free-floating and usually temporal, meaning that in heavily affected areas, during large parts of the year the bloom can create a complex three-dimensional structure that is replaced by bare sediment or naked rock (Berezina and Golubkov, 2008; Wennhage and Pihl, 2007). These changes in structure and species composition of the vegetation have a strong impact on the entire community. Organic material from decomposing macroalgal mats affect benthic meiofauna (Bohorquez et al., 2013) and often lead to anaerobic conditions and hydrogen sulfide

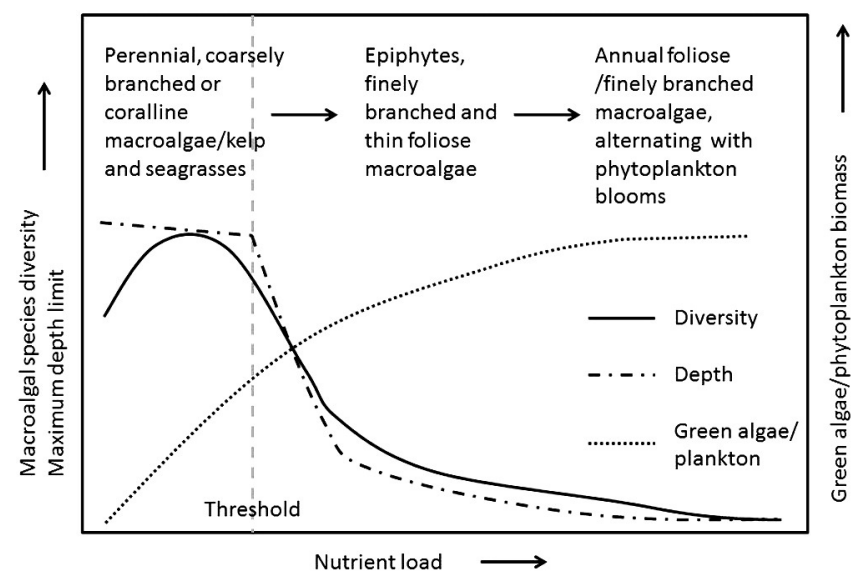

Fig. 7. Schematic summary of effects of increased nutrient loading of coastal ecosystems on macroalgal species diversity and community, maximum depth limit of macroalgae and green algal and phytoplankton biomass.

In part adapted from a tentative model of Nienhuis (1992). formation resulting in mass die-off of benthic fauna (Nicholls et al., 1981; Pihl et al., 1995; Reise, 1983) and seagrasses (e.g., the loss of a southern range Zostera marina meadow under a green mat) (Cunha et al., 2013). Evidently this also affects other trophic levels, notably juvenile stages of fish (Isaksson et al., 1994; Lenanton et al., 1985; Pihl et al., 1995) and their predators. The Veerse Meer lagoon in the Netherlands for example, before restoration attempts, had changed from a 'seagrass-fish-piscivorous birds' system into a 'green algaeherbivorous bird' (notably coots, Fulica atra and mute swans, Cygnus olor) dominated system (Coosen et al., 1990; Seys et al., 1991). Other trophic cascade effects of macroalgal blooms on birds have been reported for the Mondego estuary in Portugal (Lopes et al., 2006).

Ecosystem level effects of macroalgal blooms have been documented, but remain difficult to quantify. Comparative studies and metaanalyses are thus far very scarce if existing at all. In general, affected systems change from grazing controlled (top-down) stable systems to unstable detritus and mineralizations (bottom-up systems) that can be characterized by a high turnover of oxygen and nutrients and frequent alternations between aerobic and anaerobic states (Flindt et al., 1999) primarily impacting the functioning of the benthic ecosystems and potentially affecting neighboring systems, such as salt marsh communities (Newton and Thornber, 2013). Impacts of macroalgal blooms have been reported on benthic denitrification (Gonzalez et al., 2013), nutrient fluxes between the sediment and the water column (benthic-pelagic coupling, viz. Garcia-Robledo and Corzo, 2011; Havens et al., 2001; Sundbäck et al., 1990; Tyler et al., 2001), carbon storage capacity (Schmidt et al., 2012) and benthic carbon metabolism (Corzo et al., 2009; Pregnall and Rudy, 1985; Valiela et al., 1997). However, as Hubas and Davoult (2006) highlight, effects may be large at an hourly scale but modest at annual scale and, more importantly, most studies reflect comparisons of sediment with or without macroalgal blooms and not of seaweed communities. To obtain a coherent image of the effect of green tides on ecosystem functions there is a strong need for specific investigations in this area, addressing research questions on multiple spatial and temporal scales, carrying out cross-system comparisons (see for example Schmidt et al., 2012; Teichberg et al., 2010).

\subsubsection{Prospects}

The prospects for eutrophicated systems are quite bleak. In the latest assessment of the exposure of ecosystems to acidification, eutrophication and ozone of the European Environmental Agency (EEA, 2013), it is concluded that "the magnitude of the risk of ecosystem eutrophication and its geographical coverage has diminished only slightly over the years." Furthermore, predictions for 2010 to 2020 indicate that the risk is still widespread. Essential for recovery of ecosystems from eutrophication is the drastic reduction of nutrient loads (Morand and Merceron, 2005), although the effect of this will most likely not be immediate due to the "memory effect" of nutrient rich sediments (Artioli et al., 2008). Control of green tides can partially be obtained by other measures, such as harvesting and dredging, but this is usually not sufficient to obtain complete restoration of the original flora (Falace et al., 2009; Sfriso and Marcomini, 1996). Absence of "dormant" material (spores, seedlings) or neighboring populations are important factors that impede recolonization of restored systems and most likely active restoration is required for recovery. Thus far, we found only one example of seaweed restoration (Marzinelli et al., 2014), so we can conclude that there is a strong need for the development of theoretical and practical knowledge in this area.

To conclude, it has been shown that eutrophication of coastal waters leads to strong decreases in macroalgal species diversity and depth distribution and profound changes in the macroalgal community. Great impacts of these changes have been described on other ecosystem components. Recent research efforts have focused on linking these alterations to changes in ecosystem functioning, however much still has to be done. In particular, cross-system comparisons and meta-analyses 
would be useful to obtain a generalized picture. Prospects for restoration are murky due to the fact that eutrophication is still ongoing in many sites and studies on the restoration potential of macroalgal communities are virtually absent.

\section{Conclusions}

As reviewed in this paper seaweed diversity and community structure is highly impacted and threatened by various stressors acting at global as well as local scales. It is therefore of paramount importance to unravel the relationships between seaweed diversity, community functioning and ecosystem services. Even though our knowledge on the relation between diversity and ecosystem functioning might still be at its infancy, the importance of seaweed diversity on such divergent functions as ecosystem productivity, invader resistance or nutrient uptake stands out.

There are, however, several important knowledge gaps that prevent biologists and decision makers from anticipating, or even better mitigating, changes in the composition of seaweed communities and the accompanying ecosystem-level effects. First, baseline data on European algal species diversity and especially distribution data is still frustratingly incomplete and many records are inaccurate. Seaweed records, preferably linked to voucher specimens, are for example conspicuously absent from European or global repositories. The lack of baseline data may impede detection of range shifts, local extinctions as well as the introduction of non-native species urge the necessity to use unexplored historical records from herbarium vouchers and gray literature while studying the distribution over time and space of a given species. These problems could at least be partly resolved by making data publication (e.g. distribution records) mandatory as advocated by Costello et al. (2013). Second, to facilitate the early detection of introduced and putatively invasive seaweeds we advocate for the training of field phycologists and for a DNA-based framework that includes reference barcodes of European as well as common introduction sources, namely NW Pacific species. Using routine DNA-barcoding methods for large scale future census, avoids problems linked to morphology-based identifications (e.g. cryptic introductions) and would allow an early warning systems for newly introduced species.

The composition of seaweed communities is considered a good indicator of ecological quality, and by large the ecosystem services provided in the coastal environment is depending on these communities. Understanding the impacts of different stressors on these communities is therefore an essential step in terms of mitigation. There is a strong need for studies addressing the combined impacts of stressors. Little is known for example on the combined effect of biological invasions and climate change in seaweed communities (Olabarria et al. 2013). Loss of native diversity and changes in natural assemblages derived from the introduction of non-indigenous species might affect the ability of systems to deal with climate change stressors. Besides, changing climate might facilitate invasions by favoring introduced over native species. Models and experiments that simultaneously incorporate climate stressors and new diversity scenarios should help to understand future impacts of these changes in coastal ecosystems. In addition, the interaction of ecological and evolutionary processes at play at colonization fronts of range-shifting species is poorly understood, but important to predict future scenarios on macroevolutionary time-scales.

The present review shows the consequent effort that has been made, mostly during the past two decades, in understanding the role of seaweed communities in coastal habitats, and how any impact will affect the entire ecosystem and the services it provides. While impacts have already been apprehended in a number of cases, it also is clear that there is considerable uncertainty on long term effects. Furthermore, at least effects of local stressors may be reversible by improving water quality in cases of water pollution and eutrophication, or designing coastal defenses and artificial structures that will act as facilitators of stable seaweed communities (Firth et al., 2014). Trials in implementing dedicated artificial reefs, especially designed for seaweed key species (e.g. Choi et al., 2006; Seaman, 2007), as well as transplantation efforts (Susini et al., 2007; Gianni et al., 2013), are usually encouraging and should be part of restoration policies. Such efforts, however, may not have the same effect in mitigating impacts of global stressors such as global warming and biotic homogenization (with biological invasions as resilient biological pollution).

As the present review underlines, long term effect of global warming will cause the northward shift of present communities (impacting the genetic structure and variability of many key species), and the likely extinction of refuge populations or species that are highly valuable in terms of biodiversity, unless they can adapt to the new conditions. It is also likely to trigger irreversible change in the structure of seaweed communities by the replacement of key species that structure the habitat. Our ability to predict future scenarios will largely depend on our knowledge of coastal ecosystems. Importantly, our ability to mitigate or even reverse the effect of anthropogenic stressors on coastal environments is a common responsibility.

\section{Acknowledgments}

ODC, SV, AHE, FF, EAS and FM are indebted to EU FP7 ERANET (Project SEAS-ERA/INVASIVES SD/ER/010). FA was supported by FCT project CLEF (PTDC/ACC-AMB/102866/2008). JA was supported by FCT - Portuguese Science Foundation (Postdoc fellowship CCMAR/ BPD/0045/2013 and project EXCL/AAG-GLO/0661/2012). AHE was supported by a scholarship of the Portuguese Science Foundation (FCT: SFRH/BPD/63703/2009). EAS acknowledges support from the Portuguese Science Foundation (FCT) via project EXTANT (EXCL/AAG-GLO/ 0661/2012, to EAS).

\section{References}

Aberg, P., 1992a. A demographic-study of 2 populations of the seaweed Ascophyllum nodosum. Ecology 73, 1473-1487.

Aberg, P., 1992b. Size-based demography of the seaweed Ascophyllum nodosum in stochastic environments. Ecology 73, 1488-1501.

Afonso-Carrillo, J., Rodriguez-Prieto, C., Boisset, F., Sobrino, C., Tittley, I., Neto, A.I., 2006 Botryocladia chiajeana and Botryocladia macaronesica sp nov (Rhodymeniaceae Rhodophyta) from the Mediterranean and the eastern Atlantic, with a discussion on the closely related genus Irvinea. Phycologia 45, 277-292.

Airoldi, L., Beck, M.W., 2007. Loss, status and trends for coastal marine habitats of Europe Oceanogr. Mar. Biol. 45, 345-405.

Airoldi, L., Bulleri, F., 2011. Anthropogenic disturbance can determine the magnitude of opportunistic species responses on marine urban infrastructures. PLoS One 6, e22985.

Airoldi, L., Balata, D., Beck, M.W., 2008. The gray zone: relationships between habitat loss and marine diversity and their applications in conservation. J. Exp. Mar. Biol. Ecol. $366,8-15$.

Aleem, A.A., 1948. The recent migration of certain Indo-Pacific algae from the Red Sea into the Mediterranean. New Phytol. 47, 88-94.

Ambrose, R.F., Nelson, B.V., 1982. Inhibition of giant kelp recruitment by an introduced brown alga. Bot. Mar. 25, 265-267.

Andreakis, N., Procaccini, G., Maggs, C., Kooistra, W.H.C.F., 2007. Phylogeography of the invasive seaweed Asparagopsis (Bonnemaisoniales, Rhodophyta) reveals cryptic diversity. Mol. Ecol. 16, 2285-2299.

Appeltans, W., Ahyong, S.T., Anderson, G., Angel, M.V., Artois, T., Bailly, N., Bamber, R. Barber, A., Bartsch, I., Berta, A., Blazewicz-Paszkowycz, M., Bock, P., Boxshall, G., Boyko, C.B., Brandao, S.N., Bray, R.A., Bruce, N.L., Cairns, S.D., Chan, T.Y., Cheng, L.N., Collins, A.G., Cribb, T., Curini-Galletti, M., Dahdouh-Guebas, F., Davie, P.J.F., Dawson, M.N., De Clerck, O., Decock, W., De Grave, S., de Voogd, N.J., Domning, D.P., Emig, C.C., Erseus, C., Eschmeyer, W., Fauchald, K., Fautin, D.G., Feist, S.W., Fransen, C.H.J.M., Furuya, H., Garcia-Alvarez, O., Gerken, S., Gibson, D., Gittenberger, A., Gofas, S., Gomez-Daglio, L., Gordon, D.P., Guiry, M.D., Hernandez, F., Hoeksema, B.W. Hopcroft, R.R., Jaume, D., Kirk, P., Koedam, N., Koenemann, S., Kolb, J.B., Kristensen, R.M., Kroh, A., Lambert, G., Lazarus, D.B., Lemaitre, R., Longshaw, M., Lowry, J., Macpherson, E., Madin, L.P., Mah, C., Mapstone, G., McLaughlin, P.A., Mees, J., Meland, K., Messing, C.G., Mills, C.E., Molodtsova, T.N., Mooi, R., Neuhaus, B., Ng, P.K.L., Nielsen, C., Norenburg, J., Opresko, D.M., Osawa, M., Paulay, G., Perrin, W. Pilger, J.F., Poore, G.C.B., Pugh, P., Read, G.B., Reimer, J.D., Rius, M., Rocha, R.M., SaizSalinas, J.I., Scarabino, V., Schierwater, B., Schmidt-Rhaesa, A., Schnabel, K.E. Schotte, M., Schuchert, P., Schwabe, E., Segers, H., Self-Sullivan, C., Shenkar, N., Siegel, V., Sterrer, W., Stohr, S., Swalla, B., Tasker, M.L., Thuesen, E.V., Timm, T. Todaro, M.A., Turon, X., Tyler, S., Uetz, P., van der Land, J., Vanhoorne, B., van Ofwegen, L.P., van Soest, R.W.M., Vanaverbeke, J., Walker-Smith, G., Walter, T.C. Warren, A., Williams, G.C., Wilson, S.P., Costello, M.J., 2012. The magnitude of global marine species diversity. Curr. Biol. 22, 2189-2202. 
Araujo, R., Vaselli, S., Almeida, M., Serrao, E., Sousa-Pinto, I., 2009. Effects of disturbance on marginal populations: human trampling on Ascophyllum nodosum assemblages at its southern distribution limit. Mar. Ecol. Prog. Ser. 378, 81-92.

Araujo, R., Sousa-Pinto, I., Serrao, E.A., Aberg, P., 2012. Recovery after trampling disturbance in a canopy-forming seaweed population. Mar. Biol. 159, 697-707.

Araujo, R.M., Bartsch, I., Brekkby, T., Erzini, K., Sousa-Pinta, I., 2013. What is the impact of kelp forest density and/or area on fisheries? Environ. Evid. 2, 1-4.

Arenas, F., Sanchez, I., Hawkins, S.J., Jenkins, S.R., 2006. The invasibility of marine algal assemblages: role of functional diversity and identity. Ecology 87, 2851-2861.

Arribas, P., Abellan, P., Velasco, J., Bilton, D.T., Millan, A., Sanchez-Fernandez, D., 2012 Evaluating drivers of vulnerability to climate change: a guide for insect conservation strategies. Glob. Chang. Biol. 18, 2135-2146.

Artioli, Y., Friedrich, J., Gilbert, A.J., McQuatters-Gollop, A., Mee, L.D., Vermaat, J.E., Wulff, F., Humborg, C., Palmeri, L., Pollehne, F., 2008. Nutrient budgets for European seas: measure of the effectiveness of nutrient reduction policies. Mar. Pollut. Bull. 56 1609-1617.

Arzel, P., 1998. Les laminaires sur les côtes bretonnes. Evolution de l'exploitation et de la flottille de pêche, état actuel et perspectives. IFREMER, Plouzané.

Assis, J., Coelho, N.C., Alberto, F., Valero, M., Raimondi, P., Reed, D., Serrao, E.A., 2013. High and distinct range-edge genetic diversity despite local bottlenecks. PLoS One 8 , e68646.

Assis, J. Serrão, E. a, Claro, B., Perrin, C., Pearson, G a, 2014. Climate-driven range shifts explain the distribution of extant gene pools and predict future loss of unique lineages in a marine brown alga. Mol. Ecol. 23, 2797-2810.

Aubin, J., Papatryphon, E., van der Werf, H.M.G., Chatzifotis, S., 2009. Assessment of the environmental impact of carnivorous finfish production systems using life cycle as sessment. J. Clean. Prod. 17, 354-361.

Balata, D., Piazzi, L., Cinelli, F., 2004. A comparison among assemblages in areas invaded by Caulerpa taxifolia and C. racemosa on a subtidal Mediterranean rocky bottom. Mar. Ecol. PSZN 25, 1-13.

Ballesteros, E., 1990. Structure and dynamics of the community of Cystoseira zosteroides (Turner) C. Agardh (Fucales, Phaeophyceae) in the Northwestern Mediterranean. Sci. Mar. 54, 217-299.

Ballesteros, E., Torras, X., Pinedo, S., Garcia, M., Mangialajo, L., de Torres, M., 2007. A new methodology based on littoral community cartography dominated by macroalgae fo the implementation of the European Water Framework Directive. Mar. Pollut. Bull. 55, 172-180.

Barradas, A., Alberto, F., Engelen, A.H., Serrão, E., 2011. Fast sporophyte replacement after removal suggests banks of latent microscopic stages of Laminaria ochroleuca (Phaeophyceae) in tide pools in northern Portugal. Cah. Biol. Mar. 52, 435-439.

Behrenfeld, M., 2011. Uncertain future for ocean algae. Nat. Clim. Chang. 1, 33-34.

Belkin, M., 2009. Rapid warming of large marine ecosystems. Prog. Oceanogr. 81, 207-213.

Bellard, C., Bertelsmeier, C., Leadley, P., Thuiller, W., Courchamp, F., 2012. Impacts of climate change on the future of biodiversity. Ecol. Lett. 15, 365-377.

Berezina, N.A., Golubkov, S.M., 2008. Effect of drifting macroalgae Cladophora glomerata on benthic community dynamics in the easternmost Baltic Sea. J. Mar. Syst. 74, S80-S85.

Bergstrom, L., Tatarenkov, A., Johannesson, K., Jonsson, R.B., Kautsky, L., 2005. Genetic and morphological identification of Fucus radicans sp. nov. (Fucales, Phaeophyceae) in the brackish Baltic Sea. J. Phycol. 41, 1025-1038.

Bermejo, R., Vergara, J.J., Hernandez, I., 2012. Application and reassessment of the reduced species list index for macroalgae to assess the ecological status under the Wate Framework Directive in the Atlantic coast of Southern Spain. Ecol. Indic. 12, 46-57.

Bertness, M.D., Leonard, G.H., Levine, J.M., Bruno, J.F., 1999. Climate-driven interaction among rocky intertidal organisms caught between a rock and a hot place. Oecologia $120,446-450$

Bertuccio, C., Minicante, S.A., Manghisi, A., Genovese, G., Le Gall, L., Morabito, M., 2011. Detection of alien species in two Italian coastal lagoons using the DNA barcoding tool. Eur. J. Phycol. 46, 137

Bianchi, C.N., Corsini-Foka, M., Morri, C., Zenetos, A., 2014. Thirty years after: dramatic changes in the coastal marine ecosystems of Kos Island (Greece), 1981-2013. Mediterr. Mar. Sci. 15, 482-497.

Bigg, G.R., Cunningham, C.W., Ottersen, G., Pogson, G.H., Wadley, M.R., Williamson, P., 2008. Ice-age survival of Atlantic cod: agreement between palaeoecology models and genetics. Proc. R. Soc. B 275, 163-U113.

Birk, S., Bonne, W., Borja, A., Brucet, S., Courrat, A., Poikane, S., Solimini, A., van de Bund W.V.,Zampoukas, N., Hering. D., 2012. Three hundred ways to assess Europe's surface waters: an almost complete overview of biological methods to implement the Wate Framework Directive. Ecol. Indic. 18, 31-41.

Bitar, G., De La Grandrive, R.D., Foulquie, M., Verlaque, M., 2005. Neomeris annulata Dickie (Dasycladales, Chlorophyceae): a potential new invader from the Red Sea to the Mediterranean Sea. Cryptogam. Algol. 26, 309-317.

Bixler, H.J., Porse, H., 2011. A decade of change in the seaweed hydrocolloids industry J. Appl. Phycol. 23, 321-335.

Bohorquez, J., Papaspyrou, S., Yufera, M., van Bergeijk, S.A., Garcia-Robledo, E., JimenezArias, J.L., Bright, M., Corzo, A., 2013. Effects of green macroalgal blooms on the meiofauna community structure in the Bay of Cadiz. Mar. Pollut. Bull. 70, 10-17.

Boudouresque, C.F., 1999. The Red Sea-Mediterranean link: unwanted effects of canal. In: Sandlund, O.T., Schei, P.J., Viken, A. (Eds.), Invasive Species and Biodiversity Management. Kluwer Academic, pp. 213-228.

Boudouresque, C.F., 2003. The erosion of Mediterranean biodiversity. In: Rodríguez Prieto, C Pardini, G. (Eds.). The Mediterranean Sea: An Overview of Its Presen State and Plans for Future Protection. Servei de Publicacions de la Universitat de Girona, pp. 53-112.

Boudouresque, C.F., Verlaque, M., 2002. Biological pollution in the Mediterranean Sea: invasive versus introduced macrophytes. Mar. Pollut. Bull. 44, 32-38.
Boudouresque, C.F., K., J., Ruitton, S., Verlaque, M., 2011. Biological invasion: the Thau Lagoon, a Japanese biological island in the Mediterranean Sea. In: Ceccaldi, H.J., D., I., Girault, M., Stora, G. (Eds.), Global Change: Mankind-Marine Environment Interactions. Springer, The Netherlands.

Boyer, K.E., Kertesz, J.S., Bruno, J.F., 2009. Biodiversity effects on productivity and stability of marine macroalgal communities: the role of environmental context. Oikos 118, 1062-1072.

Bracken, M.E.S., Nielsen, K.J., 2004. Diversity of intertidal macroalgae increases with nitrogen loading by invertebrates. Ecology 85, 2828-2836.

Bracken, M.E.S., Stachowicz, J.J., 2006. Seaweed diversity enhances nitrogen uptake via complementary use of nitrate and ammonium. Ecology 87, 2397-2403.

Bracken, M.E.S., Williams, S.L., 2013. Realistic changes in seaweed biodiversity affect multiple ecosystem functions on a rocky shore. Ecology 94, 1944-1954.

Bracken, M.E.S., Friberg, S.E., Gonzalez-Dorantes, C.A., Williams, S.L., 2008. Functional consequences of realistic biodiversity changes in a marine ecosystem. Proc. Natl. Acad. Sci. U. S. A. 105, 924-928.

Brawley, S.H., Coyer, J.A., Blakeslee, A.M.H., Hoarau, G., Johnson, L.E., Byers, J.E., Stam, W.T., Olsen, J.L., 2009. Historical invasions of the intertidal zone of Atlantic North America associated with distinctive patterns of trade and emigration. Proc. Natl. Acad. Sci. U. S. A. $106,8239-8244$

Breeman, A.M., Pakker, H., 1994. Temperature ecotypes in seaweeds: adaptive significance and biogeographic implications. Bot. Mar. 37, 171-180.

Breuer, G., Schramm, W., 1988. Changes in macroalgal vegetation of Kiel Bight (Western Baltic Sea) during the past 20 years. Kiel. Meeresforsch. 6, 241-255.

Brodie, J., Bartsch, I., Neefus, C., Orfanidis, S., Bray, T., Mathieson, A.C., 2007. New insights into the cryptic diversity of the North Atlantic-Mediterranean 'Porphyra leucosticta' complex: P. olivii sp. nov. and P. rosengurttii (Bangiales, Rhodophyta). Eur. J. Phycol. 42, 3-28.

Brodie, J., Williamson, C.J., Smale, D.A., Kamenos, N.A., Mieszkowska, N., Santos, R. Cunliffe, M., Steinke, M., Yesson, C., Anderson, K.M., Asnaghi, V., Brownlee, C., Burdett, H.L., Burrows, M.T., Collins, S., Donohue, P.J.C., Harvey, B., Foggo, A., Noisette, F., Nunes, J., Ragazzola, F., Raven, J.A., Schmidt, D.N., Suggett, D., Teichberg, M. Hall-Spencer, J.M., 2014. The future of the northeast Atlantic benthic flora in a high $\mathrm{CO}_{2}$ world. Ecol. Evol. 4, 2787-2798.

Brown, C.J., Saunders, M.I., Possingham, H.P., Richardson, A.J., 2013. Managing for interactions between local and global stressors of ecosystems. PLoS One 8, e65765.

Bruno, J.F., Boyer, K.E., Duffy, J.E., Lee, S.C., Kertesz, J.S., 2005. Effects of macroalgal species identity and richness on primary production in benthic marine communities. Ecol. Lett. 8, 1165-1174.

Bruno, J.F., Lee, S.C., Kertesz, J.S., Carpenter, R.C., Long, Z.T., Duffy, J.E., 2006. Partitioning the effects of algal species identity and richness on benthic marine primary production. Oikos $115,170-178$.

Bulleri, F., Airoldi, L., 2005. Artificial marine structures facilitate the spread of a nonindigenous green alga, Codium fragile ssp tomentosoides, in the north Adriatic Sea. J. Appl. Ecol. 42, 1063-1072.

Burrows, M.T., Schoeman, D.S., Buckley, L.B., Moore, P., Poloczanska, E.S., Brander, K.M., Brown, C., Bruno, J.F., Duarte, C.M., Halpern, B.S., Holding, J., Kappel, C.V., Kiessling, W., O'Connor, M.I., Pandolfi, J.M., Parmesan, C., Schwing, F.B., Sydeman, W.J., Richardson, A.J., 2011. The pace of shifting climate in marine and terrestrial ecosystems. Science 334, 652-655.

Bustamante, R.H., Branch, G.M., 1996. The dependence of intertidal consumers on kelpderived organic matter on the west coast of South Africa. J. Exp. Mar. Biol. Ecol. 196, 1-28.

Canovas, F.G., Mota, C.F., Serrao, E.A., Pearson, G.A., 2011. Driving south: a multi-gene phylogeny of the brown algal family Fucaceae reveals relationships and recent drivers of a marine radiation. BMC Evol. Biol. 11.

Capiomont, A., Breugnot, E., Den Haan, M., Meinesz, A., 2005. Phenology of a deep water population of Caulerpa racemosa in the northwestern Mediterranean sea. Bot. Mar. $48,80-83$.

Carlton, J.T., 1996. Biological invasions and cryptogenic species. Ecology 77, 1653-1655.

Carlton, J.T., Hodder, J., 1995. Biogeography and dispersal of coastal marine organisms experimental studies on a replica of a 16th-century sailing vessel. Mar. Biol. 121, 721-730.

Carney, L.T., Edwards, M.S., 2006. Cryptic processes in the sea: a review of delayed development in the microscopic life stages of marine macroalgae. Algae 21, $161-168$

Castric-Fey, A., Beaupoil, C., Bouchain, J., Pradier, E., L'Hardy-Halos, M.T., 1999. The introduced alga Undaria pinnatifida (Laminariales, Alariaceae) in the rocky shore ecosystem of the St Malo area: growth rate and longevity of the sporophyte. Bot. Mar. 42, $83-96$.

CBD, 2006. Global Biodiversity Outlook 2. Secretariat of the Convention on Biological Diversity, Montreal, p. 81 (+ vii).

Ceccherelli, G., Piazzi, L., Balata, D., 2002. Spread of introduced Caulerpa species in macroalgal habitats. J. Exp. Mar. Biol. Ecol. 280, 1-11.

Cecere, E., Petrocelli, A., Saracino, O.D., 2000. Undaria pinnatifida (Fucophyceae, Laminariales) spread in the central Mediterranean: its occurrence in the Mar Piccolo of Taranto (Ionian Sea, southern Italy). Cryptogam. Algol. 21, 305-309.

Choi, C.G., Ohno, M., Sohn, C.H., 2006. Algal succession on different substrata covering the artificial iron reef at Ikata in Shikoku. Japan. Algae 21, 305-310.

Chung, I.K., Beardall, J., Mehta, S., Sahoo, D., Stojkovic, S., 2011. Using marine macroalgae for carbon sequestration: a critical appraisal. J. Appl. Phycol. 23, 877-886.

Cianciola, E.N. Popolizio, T., Schneider, C.W., Lane, C.E. 2010. Using molecular-assisted alpha taxonomy to better understand red algal biodiversity in Bermuda. Diversity 2, 946-958.

Clark, P.U., Dyke, A.S., Shakun, J.D., Carlson, A.E., Clark, J., Wohlfarth, B., Mitrovica, J.X., Hostetler, S.W., McCabe, A.M., 2009. The last glacial maximum. Science 325, 710-714. 
Claudet, J., Fraschetti, S., 2010. Human-driven impacts on marine habitats: a regional meta-analysis in the Mediterranean Sea. Biol. Conserv. 143, 2195-2206.

Colautti, R.I., MacIsaac, H.J., 2004. A neutral terminology to define 'invasive' species. Divers. Distrib. 10, 135-141.

Conklin, E.G., 1988. The origin of marine laboratories in Europe and America. Biol. Bull. MBL 174, 10-33.

Coosen, J., Meire, P., Stuart, J.J., Seys, J., 1990. Trophic relationships in brackish Lake Veere: the role of macrophytes. In: Barnes, M., Gibson, R.N. (Eds.), Trophic Relationships in the Marine EnvironmentProceedings of the 24th European Marine Biology Symposium. Aberdeen University Press, pp. 404-423.

Corzo, A., van Bergeijk, S.A., Garcia-Robledo, E., 2009. Effects of green macroalgal blooms on intertidal sediments: net metabolism and carbon and nitrogen contents. Mar. Ecol. Prog. Ser. 380, 81-93.

Cosson, J., 1999. On the progressive disappearance of Laminaria digitata on the coasts of Calvados (France). Cryptogam. Algol. 20, 35-42.

Costanza, R., dArge, R., deGroot, R., Farber, S., Grasso, M., Hannon, B., Limburg, K., Naeem, S., ONeill, R.V., Paruelo, J., Raskin, R.G., Sutton, P., vandenBelt, M., 1997. The value of the world's ecosystem services and natural capital. Nature 387, 253-260.

Costello, M.J., Wilson, S.P., 2011. Predicting the number of known and unknown species in European seas using rates of description. Glob. Ecol. Biogeogr. 20, 319-330.

Costello, M.J., Bouchet, P., Boxshall, G., Fauchald, K., Gordon, D., Hoeksema, B.W., Poore, G.C.B., van Soest, R.W.M., Stohr, S., Walter, T.C., Vanhoorne, B., Decock, W. Appeltans, W., 2013. Global coordination and standardisation in marine biodiversity through the World Register of Marine Species (WoRMS) and related databases. PLoS One 8, e51629.

Coyer, J.A., Hoarau, G., Costa, J.F., Hogerdijk, B., Serrao, E.A., Billard, E., Valero, M., Pearson, G.A., Olsen, J.L., 2011. Evolution and diversification within the intertidal brown macroalgae Fucus spiralis/F. vesiculosus species complex in the North Atlantic. Mol. Phylogenet. Evol. 58, 283-296.

Crain, C.M., Kroeker, K., Halpern, B.S., 2008. Interactive and cumulative effects of multiple human stressors in marine systems. Ecol. Lett. 11, 1304-1315.

Critchley, A.T., Farnham, W.F., Yoshida, T., Norton, T.A., 1990. A bibliography of the invasive alga Sargassum muticum (Yendo) Fensholt (Fucales, Sargassaceae). Bot. Mar. 33, 551-562

Cunha, A.H., Assis, J.F., Serrao, E.A., 2013. Seagrasses in Portugal: a most endangered marine habitat. Aquat. Bot. 104, 193-203.

Curiel, D., Bellemo, G., Marzocchi, M., Scattolin, M., Parisi, G., 1998. Distribution of introduced Japanese macroalgae Undaria pinnatifida, Sargassum muticum (Phaeophyta) and Antithamnion pectinatum (Rhodophyta) in the Lagoon of Venice. Hydrobiologia $385,17-22$.

DAISIE, 2014. Delivering Alien Invasive Species Inventories for Europe: European Summary. http://www.europe-aliens.org/europeSummary.do (Accessed November 2014).

Davies, A.J., Johnson, M.P., Maggs, C.A., 2007. Limpet grazing and loss of Ascophyllum nodosum canopies on decadal time scales. Mar. Ecol. Prog. Ser. 339, 131-141.

Davison, I.R., 1991. Environmental effects on algal photosynthesis: temperature. J. Phycol. 27, 2-8.

Davoult, D., Engel, C.R., Arzel, P., Knoch, D., Laurans, M., 2011. Environmental factors and commercial harvesting: exploring possible links behind the decline of the kelp Laminaria digitata in Brittany, France. Cah. Biol. Mar. 52, 429-434.

Dayton, P.K., 1975. Experimental evaluation of ecological dominance in a rocky intertidal algal community. Ecol. Monogr. 45, 137-159.

Dayton, P.K., 1985. Ecology of kelp communities. Annu. Rev. Ecol. Syst. 16, 215-245.

De Clerck, O., Gavio, B., Fredericq, S., Barbara, I., Coppejans, E., 2005. Systematics of Grateloupia filicina (Halymeniaceae, Rhodophyta), based on rbcL sequence analyses and morphological evidence, including the reinstatement of $G$. minima and the description of G. capensis sp. nov. J. Phycol. 41, 391-410.

De Clerck, O., Guiry, M.D., Leliaert, F., Samyn, Y., Verbruggen, H., 2013. Algal taxonomy: a road to nowhere? J. Phycol. 49, 215-225.

den Hartog, C., 1959. Epilithic algal communities occurring along the coasts of the Netherlands. Wentia 1-241.

Devescovi, M., Ivesa, L., 2007. Short term impact of planktonic mucilage aggregates on macrobenthos along the Istrian rocky coast (Northern Adriatic, Croatia). Mar. Pollut. Bull. 54, 887-893.

De Wreede, R.E., 1983. Sargassum muticum (Fucales, Phaeophyta): regrowth and interaction with Rhodomela larix (Ceramiales, Rhodophyta). Phycologia 22, 153-160.

Diaz-Tapia, P., Kim, M.S., Secilla, A., Barbara, I., Cremades, J., 2013. Taxonomic reassessment of Polysiphonia foetidissima (Rhodomelaceae, Rhodophyta) and similar species, including P. schneideri, a newly introduced species in Europe. Eur. J. Phycol. 48 345-362.

Didham, R.K., Tylianakis, J.M., Hutchison, M.A., Ewers, R.M., Gemmell, N.J., 2005. Are invasive species the drivers of ecological change? Trends Ecol. Evol. 20, 470-474.

Diekmann, O.E., Serrao, E.A., 2012. Range-edge genetic diversity: locally poor extant southern patches maintain a regionally diverse hotspot in the seagrass Zostera marina. Mol. Ecol. 21, 1647-1657.

Díez, I., Muguerza, N., Santolaria, A., Ganzedo, U., Gorostiaga, J.M., 2012. Seaweed assemblage changes in the eastern Cantabrian Sea and their potential relationship to climate change. Est. Coast. Shelf Sci. 99, 108-120.

Dijoux, L., Viard, F., Payri, C., 2014. The more we search, the more we find: discovery of a new lineage and a new species complex in the genus Asparagopsis. PLoS ONE 9, e103826.

Dion, P., Le Bozec, S., 1996. The French Atlantic coasts. In: Schramm, W., Nienhuis, P.H. (Eds.), Marine Benthic VegetationRecent Changes and the Effects of Eutrophication. Springer, Berlin, pp. 251-264.

Doney, S.C., Fabry, V.J., Feely, R.A., Kleypas, J.A., 2009. Ocean acidification: the other $\mathrm{CO}_{2}$ problem. Annu. Rev. Mar. Sci. 1, 169-192.

Duarte, C.M., 1995. Submerged aquatic vegetation in relation to different nutrient regimes. Ophelia 41, 87-112.
Duarte, C.M., Cebrian, J., 1996. The fate of marine autotrophic production. Limnol. Oceanogr. 41, 1758-1766.

Duarte, L., Viejo, R.M., Martinez, B., deCastro, M., Gomez-Gesteira, M., Gallardo, T., 2013. Recent and historical range shifts of two canopy-forming seaweeds in North Spain and the link with trends in sea surface temperature. Acta Oecol. 51, 1-10.

Duggins, D.O., Simenstad, C.A., Estes, J.A., 1989. Magnification of secondary production by kelp detritus in coastal marine ecosystems. Science 245, 170-173.

EC, 2000. Directive 2000/60/EC of the European Parliament and of the Council of 23 October 2000 establishing a framework for Community action in the field of water policy. Off. J. Eur. Communities L327, 1-72.

EC, 2008. Commission Decision (2008/915/EC) of 30 October 2008 establishing, pursuan to Directive 2000/60/EC of the European Parliament and of the Council, the values of the Member State monitoring system classifications as a result of the intercalibration exercise (notified under document number C(2008)6016). Off. J. Eur. Union L332, 20-44.

Edgar, G.J., Barrett, N.S., Morton, A.J., Samson, C.R., 2004. Effects of algal canopy clearance on plant, fish and macroinvertebrate communities on eastern Tasmanian reefs. J. Exp. Mar. Biol. Ecol. 312, 67-87.

EEA, 2006. The Changing Faces of Europe's Coastal Areas. p. 112

EEA, 2013. Exposure of Ecosystems to Acidification, Eutrophication and Ozone (CSI 005) Assessment Published Dec 2013. European Environment Agency.

Elton, C.S., 1958. The Ecology of Invasions by Animals and Plants. Methuen, London.

Engelen, A.H., Lévèque, L., Destombe, C., Valero, M., 2011. Spatial and temporal patterns of recovery of low intertidal Laminaria digitata after experimental spring and autumn removal. Cah. Biol. Mar. 52, 441-453.

Engelen, A., Santos, R., 2009. Which demographic traits determine population growth in the invasive brown seaweed Sargassum muticum? J. Ecol. 97, 675-684.

Eriksson, B.K., Johansson, G., Snoeijs, P., 2002. Long-term changes in the macroalgal vegetation of the inner Gullmar Fjord, Swedish Skagerrak coast. J. Phycol. 38, 284-296.

Estes, J.A., Duggins, D.O., Rathbun, G.B., 1989. The ecology of extinctions in kelp forest communities. Conserv. Biol. 3, 252-264.

Falace, A., Curiel, D., Sfriso, A., 2009. Study of the macrophyte assemblages and application of phytobenthic indices to assess the ecological status of the Marano-Grado Lagoon (Italy). Mar. Ecol. Evol. Perspect. 30, 480-494.

Falace, A., Alongi, G., Cormaci, M., Furnari, G., Curiel, D., Cecere, E., Petrocelli, A., 2010 Changes in the benthic algae along the Adriatic Sea in the last three decades. Chem. Ecol. 26 (S1), 77-90.

Falkowski, P., 2012. Ocean Science: the power of plankton. Nature 483, S17-S20.

Farnham, W.F., Fletcher, R.L., Irvine, L.M., 1973. Attached Sargassum found in Britain. Nature 243, 231-232.

Feldmann, J., 1937. Recherches sur la végétation marine de la Méditerranée. La Côte des Albères. Rev. Algol. 10, 1-339.

Fernandez, C., 1999. Ecology of Sargassum muticum (Phaeophyta) on the north coast of Spain: IV. Sequence of colonization on a shore. Bot. Mar. 42, 553-562.

Fernandez, C., 2011. The retreat of large brown seaweeds on the north coast of Spain: the case of Saccorhiza polyschides. Eur. J. Phycol. 46, 352-360.

Firth, L.B., Thompson, R.C., Bohn, K., Abbiati, M., Airoldi, L., Bouma, T.J., Bozzeda, F., Ceccherelli, V.U., Colangelo, M.A., Evans, A., Ferrario, F., Hanley, M.E., Hinz, H., Hoggart, S.P.G., Jackson, J.E., Moore, P., Morgan, E.H., Perkol-Finkel, S., Skov, M.W., Strain, E.M., van Belzen, J., Hawkins, S.J., 2014. Between a rock and a hard place: environmental and engineering considerations when designing coastal defence structures. Coast. Eng. 87, 122-135.

Filbee-Dexter, K., Scheibling, R.E., 2014. Sea urchin barrens as alternative stable states of collapsed kelp ecosystems. Mar. Ecol. Prog. Ser. 495, 1-25.

Flagella, M.M., Verlaque, M., Soria, A., Buia, M.C., 2007. Macroalgal survival in ballast water tanks. Mar. Pollut. Bull. 54, 1395-1401.

Fletcher, R.L., 1996. The occurrence of "green tides" - a review. In: Schramm, W., Nienhuis, P.H. (Eds.), Marine Benthic VegetationRecent Changes and the Effects of Eutrophication. Springer, Berlin, pp. 7-44.

Flindt, M.R., Pardal, J.A., Lillebo, A.I., Martins, I., Marques, J.C., 1999. Nutrient cycling and plant dynamics in estuaries: a brief review. Acta Oecol. 20, 237-248.

Forrestal, F., Coll, M., Die, D.J., Christensen, V., 2012. Ecosystem effects of bluefin tuna Thunnus thynnus thynnus aquaculture in the NW Mediterranean Sea. Mar. Ecol. Prog. Ser. 456, 215-231.

Fox, S.E., Teichberg, M., Valiela, I., Heffner, L., 2012. The relative role of nutrients, grazing, and predation as controls on macroalgal growth in the Waquoit Bay estuarine system. Estuar Coast 35, 1193-1204.

Frangoudes, K., 2011. Seaweeds fisheries management in France, Japan, Chile and Norway. Cah. Biol. Mar. 52, 517-525.

Fraschetti, S., Terlizzi, A., Guarnieri, G., Pizzolante, F., D'Ambrosio, P., Maiorano, P., Beqiraj, S., Boero, F., 2011. Effects of unplanned development on marine biodiversity: a lesson from Albania (central Mediterranean Sea). J. Coast. Res. 58, 106-115.

Galil, B.S., 2006. The Marine Caravan - The Suez Canal and the Erythrean Invasion. In: Gollasch, S., Galil, B.S., Andrew, N. (Eds.), Bridging divides: Maritime canals as invasion corridors. Monographiae Biologicae 83, pp. 207-300.

Galil, B.S., Marchini, A., Occhipinti-Ambrogi, A., Minchin, D., Narscius, A., Ojaveer, H. Olenin, S., 2014. International arrivals: widespread bioinvasions in European Seas. Ethol. Ecol. Evol. 26, 152-171.

Gamfeldt, L., Bracken, B.A., 2009. The role of diversity for the functioning of rocky reef communities. In: Wahl, M. (Ed.), Marine Hard Bottom Communities: Patterns, Dynamics, Diversity, and Change. Springer, Dordrecht; New York, p. xxiv (445 pp. Marine Hard Bottom Communities: Patterns, Dynamics, Diversity, and Change. Springer, pp. 361-373).

Gamfeldt, L., Hillebrand, H., 2008. Biodiversity effects on aquatic ecosystem functioning maturation of a new paradigm. Int. Rev. Hydrobiol. 93, 550-564. 
Gamfeldt, L., Lefcheck, J.S., Byrnes, J.E., Cardinale, B.J., Duffy, J.E., Griffin, J.N., 2014. Marine biodiversity and ecosystem functioning: what's known and what's next? PeerJ PrePrints 2, e249v1.

Gao, K., Mckinley, K.R., 1994. Use of macroalgae for marine biomass production and $\mathrm{CO}_{2}$ remediation - a review. J. Appl. Phycol. 6, 45-60.

Gao, K.S., Helbling, E.W., Hader, D.P., Hutchins, D.A., 2012a. Responses of marine primary producers to interactions between ocean acidification, solar radiation, and warming Mar. Ecol. Prog. Ser. 470, 167-189.

Gao, K.S., Xu, J.T., Gao, G., Li, Y.H., Hutchins, D.A., Huang, B.Q., Wang, L., Zheng, Y., Jin, P., Cai, X.N., Hader, D.P., Li, W., Xu, K., Liu, N.N., Riebesell, U., 2012b. Rising $\mathrm{CO}_{2}$ and increased light exposure synergistically reduce marine primary productivity. Nat. Clim. Chang. 2, 519-523.

Garcia-Jimenez, P., Geraldino, P.J.L., Boo, S.M., Robaina, R.R., 2008. Red alga Grateloupia imbricata (Halymeniaceae), a species introduced into the Canary Islands. Phycol. Res. 56, 166-171.

Garcia-Robledo, E., Corzo, A., 2011. Effects of macroalgal blooms on carbon and nitrogen biogeochemical cycling in photoautotrophic sediments: an experimental mesocosm. Mar. Pollut. Bull. 62, 1550-1556.

Gattuso, J.P., Frankignoulle, M., Wollast, R., 1998. Carbon and carbonate metabolism in coastal aquatic ecosystems. Annu. Rev. Ecol. Syst. 29, 405-434.

Gavio, B., Fredericq, S., 2002. Grateloupia turuturu (Halymeniaceae, Rhodophyta) is the correct name of the non-native species in the Atlantic known as Grateloupia doryphora. Eur. J. Phycol. 37, 349-359.

Gevaert, F., Janquin, M.A., Davoult, D., 2008. Biometrics in Laminaria digitata: a useful too to assess biomass, carbon and nitrogen contents. J. Sea Res. 60, 215-219.

Giaccone, G., Alongi, G., Pizzuto, F., Cossu, A., 1994. La Vegetazione marina bentonica fotofila del Mediterraneo: 2.: Infralitorale e Circalitorale: proposte di aggiornamento. Boll. Accad. Gioenia Sci. Nat. Catania 27 (346), 111-157.

Giakoumi, S., Cebrian, E. Kokkoris, G.D. Ballesteros, E. Sala, E, 2012. Relationships between fish, sea urchins and macroalgae: the structure of shallow rocky sublittora communities in the Cyclades, Eastern Mediterranean. Estuar. Coast. Shelf Sci. 109 $1-10$.

Gianni, F., Bartolini, F., Airoldi, L., Ballesteros, E., Francour, P., Guidetti, P., Meinesz, A Thibaut, T., Mangialajo, L., 2013. Conservation and restoration of marine forests in the Mediterranean Sea and the potential role of Marine Protected Areas. Adv. Oceanogr. Limnol. 4, 83-101.

Glasby, T.M., Connell, S.D., Holloway, M.G., Hewitt, C.L., 2007. Nonindigenous biota on artificial structures: could habitat creation facilitate biological invasions? Mar. Biol. 151 887-895.

Gonzalez, D.J., Smyth, A.R., Piehler, M.F., McGlathery, K.J., 2013. Mats of the nonnative macroalga, Gracilaria vermiculophylla, alter net denitrification rates and nutrient fluxes on intertidal mudflats. Limnol. Oceanogr. 58, 2101-2108.

Graham, M.H., 2004. Effects of local deforestation on the diversity and structure of Southern California giant kelp forest food webs. Ecosystems 7, 341-357.

Griffin, J.N., MEndez, V., Johnson, A.F., Jenkins, S.R., Foggo, A., 2009. Functional diversity predicts overyielding effect of species combination on primary productivity. Oikos $118,37-44$

Guiry, M.D., 2012. How many species of algae are there? J. Phycol. 48, 1057-1063.

Guiry, M.D., Guiry, G.M., 2014. Algaebase. National University of Ireland, Galway.

Halpern, B.S., Walbridge, S., Selkoe, K.A., Kappel, C.V., Micheli, F., D'Agrosa, C., Bruno, J.F., Casey, K.S., Ebert, C., Fox, H.E., Fujita, R., Heinemann, D., Lenihan, H.S., Madin, E.M.P. Perry, M.T., Selig, E.R., Spalding, M., Steneck, R., Watson, R., 2008. A global map of human impact on marine ecosystems. Science 319, 948-952.

Hampe, A., Petit, R.J., 2005. Conserving biodiversity under climate change: the rear edge matters. Ecol. Lett. 8, 461-467.

Hardy, F.G., Guiry, M.D., 2003. A Check-list and Atlas of the Seaweeds of Britain and Ireland. British Phycological Society.

Harley, C.D.G., Paine, R.T., 2009. Contingencies and compounded rare perturbations dictate sudden distributional shifts during periods of gradual climate change. Proc Natl. Acad. Sci. U. S. A. 106, 11172-11176.

Harley, C.D.G., Hughes, A.R., Hultgren, K.M., Miner, B.G., Sorte, C.J.B., Thornber, C.S. Rodriguez, L.F., Tomanek, L., Williams, S.L., 2006. The impacts of climate change in coastal marine systems. Ecol. Lett. 9, 228-241.

Harley, C.D.G., Anderson, K.M., Demes, K.W., Jorve, J.P., Kordas, R.L., Coyle, T.A., Graham, M.H., 2012. Effects of climate change on global seaweed communities. J. Phycol. 48, $1064-1078$

Harvey, B.P., Gwynn-Jones, D., Moore, P.J., 2013. Meta-analysis reveals complex marine biological responses to the interactive effects of ocean acidification and warming. Ecol. Evol. 3, 1016-1030

Hauxwell, J., Cebrián, J., Furlong, C., Valiela, I., 2001. Macroalgal canopies contribute to eelgrass (Zostera marina) decline in temperate estuarine ecosystems. Ecology 82, 1007-1022.

Havens, K.E., Hauxwell, J., Tyler, A.C., Thomas, S., McGlathery, K.J., Cebrian, J., Valiela, I., Steinman, A.D., Hwang, S.J., 2001. Complex interactions between autotrophs in shalow marine and freshwater ecosystems: implications for community responses to nutrient stress. Environ. Pollut. 113, 95-107.

Hays, J.D., Imbrie, J., Shackleton, N.J., 1976. Variations in the Earth's orbit: pacemaker of the ice ages. Science 194, 1121-1132.

Hepburn, C.D., Pritchard, D.W., Cornwall, C.E., McLeod, R.J., Beardall, J., Raven, J.A Hurd, C.L., 2011. Diversity of carbon use strategies in a kelp forest community: implications for a high $\mathrm{CO}_{2}$ ocean. Global Change Biol. 17, 2488-2497.

Hereu, B., Zabala, M., Linares, C., Sala, E., 2005. The effects of predator abundance and habitat structural complexity on survival of juvenile sea urchins. Mar. Biol. 146, 293-299.

Hewitt, C.L., Campbell, M.L., Schaffelke, B., 2007. Introductions of seaweeds: accidental transfer pathways and mechanisms. Bot. Mar. 50, 326-337.
Hoarau, G., Coyer, J.A., Veldsink, J.H., Stam, W.T., Olsen, J.L., 2007. Glacial refugia and recolonization pathways in the brown seaweed Fucus serratus. Mol. Ecol. 16, 3606-3616.

Hooper, D.U., Adair, E.C., Cardinale, B.J., Byrnes, J.E.K., Hungate, B.A., Matulich, K.L., Gonzalez, A., Duffy, J.E., Gamfeldt, L., O'Connor, M.I., 2012. A global synthesis reveals biodiversity loss as a major driver of ecosystem change. Nature 486, 105-108.

Hubas, C., Davoult, D., 2006. Does seasonal proliferation of Enteromorpha sp affect the annual benthic metabolism of a small macrotidal estuary? (Roscoff Aber Bay, France). Estuar. Coast. Shelf Sci. 70, 287-296.

Husa, V., Sjotun, K., Brattenborg, N., Lein, T.E., 2008. Changes of macroalgal biodiversity in sublittoral sites in southwest Norway: impact of an introduced species or higher temperature? Mar. Biol. Res. 4, 414-428.

IPCC, 2007. Climate Change 2007: The Physical Science Basis-Summary for Policymakers. Contribution of Working Group I to the Fourth Assessment Report of the Intergovernmental Panel on Climate Change (Paris). In: Solomon, S., Qin, D., Manning, M., Chen, Z., Marquis, M., Averyt, K.B., Tignor, M., Miller, H.L. (Eds.), Cambridge University Press, UK

Isaksson, I., Pihl, L., Vanmontfrans, J., 1994. Eutrophication related changes in macrovegetation and foraging of young cod (Gadus morhua L.) - a mesocosm experiment. J. Exp. Mar. Biol. Ecol. 177, 203-217.

ISSG, 2014. Global Invasive Species Database. http://www.issg.org/database.

Jones, C.G., Lawton, J.H., Shachak, M., 1994. Organisms as ecosystem engineers. Oikos 69, 373-386.

Jousson, O., Pawlowski, J., Zaninetti, L., Meinesz, A., Boudouresque, C.F., 1998. Molecular evidence for the aquarium origin of the green alga Caulerpa taxifolia introduced to the Mediterranean Sea. Mar. Ecol. Prog. Ser. 172, 275-280.

Jousson, O., Pawlowski, J., Zaninetti, L., Zechman, F.W., Dini, F., Di Guiseppe, G., Woodfield, R., Millar, A., Meinesz, A., 2000. Invasive alga reaches California. Nature 408, 157-158.

Jueterbock, A., Tyberghein, L., Verbruggen, H., Coyer, J.A., Olsen, J.L., Hoarau, G., 2013. Climate change impact on seaweed meadow distribution in the North Atlantic rocky intertidal. Ecol. Evol. 3, 1356-1373.

Kaehler, S., Pakhomov, E.A., McQuaid, C.D., 2000. Trophic structure of the marine food web at the Prince Edward Islands (Southern Ocean) determined by $\delta^{13} \mathrm{C}$ and $\delta^{15} \mathrm{~N}$ analysis. Mar. Ecol. Prog. Ser. 208, 13-20.

Kelly, R.P., Palumbi, S.R., 2010. Genetic structure among 50 species of the Northeastern Pacific rocky intertidal community. PLoS One 5, e8594.

Keough, M.J., Quinn, G.P., 1998. Effects of periodic disturbances from trampling on rocky intertidal algal beds. Ecol. Appl. 8, 141-161.

Kinlan, B.P., Gaines, S.D., 2003. Propagule dispersal in marine and terrestrial environments: a community perspective. Ecology 84, 2007-2020.

Kinlan, B.P., Graham, M.H., Sala, E., Dayton, P.K., 2003. Arrested development of giant kelp (Macrocystis pyrifera, Phaeophyceae) embryonic sporophytes: a mechanism for delayed recruitment in perennial kelps? J. Phycol. 39, 47-57.

Komatsu, T., Fukuda, M., Mikami, A., Mizuno, S., Kantachumpoo, A., Tanoue, H., Kawamiya, M., 2014. Possible change in distribution of seaweed, Sargassum horneri, in northeast Asia under A2 scenario of global warming and consequent effect on some fish. Mar. Pollut. Bull. 85, 317-324

Kroeker, K.J., Kordas, R.L., Crim, R.N., Singh, G.G., 2010. Meta-analysis reveals negative yet variable effects of ocean acidification on marine organisms. Ecol. Lett. 13, 1419-1434.

Leliaert, F., Zhang, X.W., Ye, N.H., Malta, E., Engelen, A.H., Mineur, F., Verbruggen, H., De Clerck, O., 2009. Research note: identity of the Qingdao algal bloom. Phycol. Res. 57, 147-151.

Leliaert, F., Verbruggen, H., Vanormelingen, P., Steen, F., López-Bautista, J.M., Zuccarello, G.C., De Clerck, O., 2014. DNA-based species delimitation in algae. Eur. J. Phycol. 49, 179-196.

Lenanton, R.C.J., Loneragan, N.R., Potter, I.C., 1985. Blue-green algal blooms and the commercial fishery of a large Australian estuary. Mar. Pollut. Bull. 16, 477-482.

Letts, E.A., Richards, E.H., 1911. Report on green seaweeds (and especially Ulva latissima) in relation to the pollution of the waters in which they occur. Royal Commission on Sewage Disposal. 7th report, section II, appendix III., London.

Li, R., Brawley, S.H., 2004. Improved survival under heat stress in intertidal embryos (Fucus spp.) simultaneously exposed to hypersalinity and the effect of parental thermal history. Mar. Biol. 144, 205-213.

Lima, F.P., Ribeiro, P.A., Queiroz, N., Hawkins, S.J., Santos, A.M., 2007. Do distributional shifts of northern and southern species of algae match the warming pattern? Glob. Chang. Biol. 13, 2592-2604.

Lima, F.P., Wethey, D.S., 2012. Three decades of high-resolution coastal sea surface temperatures reveal more than warming. Nat. Commun. 3, 704. http://dx.doi.org/10. 1038/ncomms1713.

Liu, D.Y., Keesing, J.K., He, P.M., Wang, Z.L., Shi, Y.J., Wang, Y.J., 2013a. The world's largest macroalgal bloom in the Yellow Sea, China: formation and implications. Estuar. Coast. Shelf Sci. 129, 2-10.

Liu, F., Pang, S., Chopin, T., Gao, S., Shan, T., Zhao, X., Li, J., 2013b. Understanding the recurrent large-scale green tide in the Yellow Sea: temporal and spatial correlations between multiple geographical, aquacultural and biological factors. Mar. Environ. Res. 83, 38-47.

Lopes, R.J., Pardal, M.A., Murias, T., Cabral, J.A., Marques, J.C., 2006. Influence of macroalgal mats on abundance and distribution of dunlin Calidris alpina in estuaries: a long-term approach. Mar. Ecol. Prog. Ser. 323, 11-20.

Lorentsen, S.H., Sjotun, K., Gremillet, D., 2010. Multi-trophic consequences of kelp harvest. Biol. Conserv. 143, 2054-2062.

Lotze, H.K., Schramm, W., Schories, D., Worm, B., 1999. Control of macroalgal blooms at early developmental stages: Pilayella littoralis versus Enteromorpha spp. Oecologia $119,46-54$. 
MacDougall, A.S., Turkington, R., 2005. Are invasive species the drivers or passengers of change in degraded ecosystems? Ecology 86, 42-55.

Mačić, V., Antolic, B., Thibaut, T., Svircev, Z., 2010. Distribution of the most common Cystoseira C. Agardh species (Heterokontophyta, Fucales) on the coast of Montenegro (south-east Adriatic sea). Fresenius Environ. Bull. 19, 1191-1198.

Maggs, C.A., Le Gall, L., Mineur, F., Provan, J., Saunders, G.W., 2013. Fredericqia deveauniensis, gen et sp. nov. (Phyllophoraceae, Rhodophyta), a new cryptogenic species. Cryptogam. Algol. 34, 273-296.

Malta, E.J., Verschuure, J.M., 1997. Effects of environmental variables on between-year variation of Ulva growth and biomass in a eutrophic brackish lake. J. Sea Res. 38 , 71-84.

Malta, E.J., Verschuure, J.M., Nienhuis, P.H., 2002. Regulation of spatial and seasonal variation of macroalgal biomass in a brackish, eutrophic lake. Helgol. Mar. Res. 56, 211-220.

Malta, E., Rijstenbil, J.W., Brouwer, P.E.M., Kromkamp, J.C., 2003. Vertical heterogeneity in physiological characteristics of Ulva spp. mats. Mar. Biol. 143, 1029-1038.

Malta, E.J., Morales, J., Jiménez, C., Santos, R., 2011. Assessing quality of coastal waters using opportunistic macroalgae, experiences from southwest Europe. Eur. J. Phycol. 46, 71 .

Manghisi, A., Morabito, M., Bertuccio, C., Gall, L.L.E., Couloux, A., Cruaud, C., Genovese, G., 2010. Is routine DNA barcoding an efficient tool to reveal introductions of alien macroalgae? A case study of Agardhiella subulata (Solieriaceae, Rhodophyta) in Cape Peloro lagoon (Sicily, Italy). Cryptogam. Algol. 31, 423-433.

Mann, K.H., 1973. Seaweeds - their productivity and strategy for growth. Science 182 975-981.

Martinez, B., Arenas, F., Rubal, M., Burgues, S., Esteban, R., Garcia-Plazaola, I., Figueroa, F.L. Pereira, R., Saldana, L., Sousa-Pinto, I., Trilla, A., Viejo, R.M., 2012. Physical factors driving intertidal macroalgae distribution: physiological stress of a dominant fucoid at its southern limit. Oecologia 170, 341-353.

Marzinelli, E.M., Campbell, A.H., Vergés, A., Coleman, M.A., Kelaher, B.P., Steinberg, P.D., 2014. Restoring seaweeds: does the declining fucoid Phyllospora comosa support different biodiversity than other habitats? J. Appl. Phycol. 26, 1089-1096.

McIvor, L., Maggs, C.A., Provan, J., Stanhope, M.J., 2001. rbcL sequences reveal multiple cryptic introductions of the Japanese red alga Polysiphonia harveyi. Mol. Ecol. 10, 911-919.

McKinney, M.L., Lockwood, J.L., 1999. Biotic homogenization: a few winners replacing many losers in the next mass extinction. Trends Ecol. Evol. 14, 450-453.

Meinesz, A., Belsher, T., Thibaut, T., Antolic, B., Ben Mustapha, K., Boudouresque, C.-F., Chiaverini, D., Cinelli, F., Cottalorda, J.-M., Djellouli, A., El Abed, A., Orestano, C., Grau, A.M., Iveša, L., Jaklin, A., Langar, H., Massuti-Pascual, E., Peirano, A., Tunesi, L., de Vaugelas, J., Zavodnik, N., Zuljevic, A., 2001. The introduced green alga Caulerpa taxifolia continues to spread in the Mediterranean. Biol. Invasions 3, 201-210.

Mesnildrey, L., Jacob, C., Frangoudes, K., Reunavot, M., Lesueur, M., 2012. Seaweed industry in France. Report. Interreg program NETALGAE, Les publications du Pôle halieutique AGROCAMPUS OUEST, pp. 1-34.

Middelboe, A.L., Binzer, T., 2004. Importance of canopy structure on photosynthesis in single- and multi-species assemblages of marine macroalgae. Oikos 107, 422-432.

Middelboe, A.L., Sand-Jensen, K., 2000. Long-term changes in macroalgal communities in a Danish estuary. Phycologia 39, 245-257.

Middelboe, A.L., Sand-Jensen, K., Krause-Jensen, D., 1998. Patterns of macroalgal species diversity in Danish estuaries. J. Phycol. 34, 457-466.

Milazzo, M., Chemello, R., Badalamenti, F., Riggio, S., 2002. Short-term effect of human trampling on the upper infralittoral macroalgae of Ustica Island MPA (western Mediterranean, Italy). J. Mar. Biol. Assoc. UK 82, 745-748.

Minchin, D., Nunn, J., 2014. The invasive brown alga Undaria pinnatifida (Harvey) Suringar, 1873 (Laminariales: Alariaceae), spreads northwards in Europe BioInvasions Records 3 (2), 57-63.

Mineur, F., Johnson, M.P., Maggs, C.A., Stegenga, H., 2007. Hull fouling on commercial ships as a vector of macroalgal introduction. Mar. Biol. 151, 1299-1307.

Mineur, F., Johnson, M.P., Maggs, C.A., 2008. Non-indigenous marine macroalgae in native communities: a case study in the British Isles. J. Mar. Biol. Assoc. UK 88, 693-698.

Mineur, F., Davies, A.J., Maggs, C.A., Verlaque, M., Johnson, M.P., 2010a. Fronts, jumps and secondary introductions suggested as different invasion patterns in marine species, with an increase in spread rates over time. Proc. R. Soc. B 277, 2693-2701.

Mineur, F., De Clerck, O., Le Roux, A., Maggs, C.A., Verlaque, M., 2010b. Polyopes lancifolius (Halymeniales, Rhodophyta), a new component of the Japanese marine flora introduced to Europe. Phycologia 49, 86-96.

Mineur, F., Cook, E.J., Minchin, D., Bohn, K., MacLeod, A., Maggs, C.A., 2012a. Changing coasts: marine aliens and artificial structures. Oceanogr. Mar. Biol. 50, 189-234.

Mineur, F., Le Roux, A., Stegenga, H., Verlaque, M., Maggs, C.A., 2012b. Four new exotic red seaweeds on European shores. Biol. Invasions 14, 1635-1641.

Mineur, F., Le Roux, A., Maggs, C.A., Verlaque, M., 2014. Positive feedback loop between introductions of non-native marine species and cultivation of oysters in Europe. Conserv. Biol. 28, 1667-1676.

Molenaar, H., Meinesz, A., Thibaut, T., 2009. Alterations of the structure of Posidonia oceanica beds due to the introduced alga Caulerpa taxifolia. Sci. Mar. 73, 329-335.

Morand, P., Briand, X., 1996. Excessive growth of macroalgae: a symptom of environmental disturbance. Bot. Mar. 39, 491-516.

Morand, P., Merceron, M., 2005. Macroalgal population and sustainability. J. Coastal Res. 21, 1009-1020.

Moy, F.E., Christie, H.C., 2012. Large-scale shift from sugar kelp (Saccharina latissima) to ephemeral algae along the south and west coast of Norway. Mar. Biol. Res. 8, 309-321.

Munda, I.M., 1967. Changes in the algal vegetation of a part of the Deltaic area in the Southern Netherlands (Veerse Meer) after its closure. Bot. Mar. 10, 141-157.

Munda, I.M., 1993. Changes and degradation of seaweed stands in the Northern Adriatic. Hydrobiologia 260 (261), 239-253.
Munday, P.L., Warner, R.R., Monro, K., Pandolfi, J.M., Marshall, D.J., 2013. Predicting evolutionary responses to climate change in the sea. Ecol. Lett. 16, 1488-1500.

Naeem, S., 2002. Ecosystem consequences of biodiversity loss: the evolution of a paradigm. Ecology 83, 1537-1552.

Neiva, J., Pearson, G.A., Valero, M., Serrao, E.A., 2010. Surfing the wave on a borrowed board: range expansion and spread of introgressed organellar genomes in the seaweed Fucus ceranoides L. Mol. Ecol. 19, 4812-4822.

Neiva, J., Pearson, G.A., Valero, M., Serrao, E.A., 2012. Drifting fronds and drifting alleles: range dynamics, local dispersal and habitat isolation shape the population structure of the estuarine seaweed Fucus ceranoides. J. Biogeogr. 39, 1167-1178.

Neiva, J., Assis, J., Fernandes, F., Pearson, G.A., Serrão, E.A., 2014. Species distribution models and mitochondrial DNA phylogeography suggest an extensive biogeographical shift in the high-intertidal seaweed Pelvetia canaliculata. J. Biogeogr. 41 $1137-1148$

Nelson, W.A., 2009. Calcified macroalgae - critical to coastal ecosystems and vulnerable to change: a review. Mar. Freshw. Res. 60, 787-801.

Nelson, T.A., Nelson, A.V., Tjoelker, M., 2003. Seasonal and spatial patterns of "green tides" (ulvoid algal blooms) and related water quality parameters in the coastal waters of Washington state, USA. Bot. Mar. 46, 263-275.

Neto, J.M., Gaspar, R., Pereira, L., Marques, J.C., 2012. Marine Macroalgae Assessment Tool (MarMAT) for intertidal rocky shores. Quality assessment under the scope of the European Water Framework Directive. Ecol. Indic. 19, 39-47.

Newton, C., Thornber, C., 2013. Ecological impacts of macroalgal blooms on salt marsh communities. Estuar. Coast 36, 365-376

Nicastro, K.R., Zardi, G.I., Teixeira, S., Neiva, J., Serrao, E.A., Pearson, G.A., 2013. Shift happens: trailing edge contraction associated with recent warming trends threatens distinct genetic lineage in the marine macroalga Fucus vesiculosus. BMC Biol. 11.

Nicholls, D.J., Tubbs, C.R., Haynes, F.N., 1981. The effect of green algal mats on intertida macrobenthic communities and their predators. Kiel. Meeresforsch. Sonderh. 5, 511-520.

Nienhuis, P.H., 1992. Ecology of coastal lagoons in The Netherlands (Veerse Meer and Grevelingen). Vie Milieu 42, 59-72.

Norton, T.A., 1977. Ecological experiments with Sargassum muticum. J. Mar. Biol. Assoc. UK 57, 33-43.

Norton, T.A., 1981. Gamete expulsion and release in Sargassum muticum. Bot. Mar. 24 465-470.

O'Connor, K.C., Anderson, T.W., 2010. Consequences of habitat disturbance and recovery to recruitment and the abundance of kelp forest fishes. J. Exp. Mar. Biol. Ecol. 386 $1-10$.

O'Connor, M.I., Selig, E.R., Pinsky, M.L., Altermatt, F., 2012. Toward a conceptual synthesis for climate change responses. Glob. Ecol. Biogeogr. 21, 693-703.

Odum, E., 1959. Fundamentals of Ecology. 2nd edition. W.B. Saunders Co.

Okuda, K., 2008. Coastal environment and seaweed-bed ecology in Japan. Kuroshio Sci. 2, $15-20$.

Olabarria, C., Arenas, F., Viejo, R.M., Gestoso, I., Vaz-Pinto, F., Incera, M., Rubal, M., Cacabelos, E., Veiga, P., Sobrino, C., 2013. Response of macroalgal assemblages from rockpools to climate change: effects of persistent increase in temperature and $\mathrm{CO}_{2}$. Oikos 122, 1065-1079.

Olden, J.D., Poff, N.L., 2004. Clarifying biotic homogenization. Trends Ecol. Evol. 19, $283-284$.

Olenin, S., Elliott, M., Bysveen, I., Culverhouse, P.F., Daunys, D., Dubelaar, G.B.J., Gollasch, S. Goulletquer, P., Jelmert, A., Kantor, Y., Mezeth, K.B., Minchin, D., Occhipinti-Ambrogi, A., Olenina, I., Vandekerkhove, J., 2011. Recommendations on methods for the detection and control of biological pollution in marine coastal waters. Mar. Pollut. Bull. 62 2598-2604.

Orfanidis, S., Panayotidis, P., Stamatis, N., 2003. An insight to the ecological evaluation index (EEI). Ecol. Indic. 3, 27-33.

Orr, M., Zimmer, M., Jelinski, D.E., Mews, M., 2005. Wrack deposition on different beach types: spatial and temporal variation in the pattern of subsidy. Ecology 86 1496-1507.

Otto-Bliesner, B.L., Brady, E.C., Clauzet, G., Tomas, R., Levis, S., Kothavala, Z., 2006. Last Glacial Maximum and Holocene climate in CCSM3. J. Clim. 19, 2526-2544.

Parmesan, C., 2006. Ecological and evolutionary responses to recent climate change Annu. Rev. Ecol. Evol. Syst. 37, 637-669.

Pearson, G.A., Lago-Leston, A., Mota, C., 2009. Frayed at the edges: selective pressure and adaptive response to abiotic stressors are mismatched in low diversity edge populations. J. Ecol. 97, 450-462.

Peltier, W.R., 1994. Ice-age paleotopography. Science 265, 195-201.

Pereira, T.R., Engelen, A.H., Pearson, G., Serrão, E., Destombe, C., Valero, M., 2011 Temperature effects on gametophyte development of Laminaria ochroleuca and Sacchoriza polyschides, kelps with contrasting life histories. Cah. Biol. Mar. 52, 395-403.

Pereyra, R.T., Bergstrom, L., Kautsky, L., Johannesson, K., 2009. Rapid speciation in a newly opened postglacial marine environment, the Baltic Sea. BMC Evol. Biol. 9.

Pérez, R., Lee, J.Y., Juge, C., 1981. Observations sur la biologie de l'algue japonaise Undaria pinnatifida (Harvey) Suringar introduite accidentellement dans l'étang de Thau. Sci. Pêche Bull. Inst. Sci. Pêches Marit. 343, 3-15.

Pergent, G., Bazairi, H., Nike Bianchi, C., Boudouresque, C.F., Buia, M.C., Calvo, S., Clabaut, P. Harmelin-Vivien, M., Mateo, M.A., Montefalcone, M., Morri, C., Orfanidis, S., PergentMartini, C., Semroud, R., Serrano, O., Thibaut, T., Tomasello, A., Verlaque, M., 2014 Climate change and Mediterranean seagrass meadows: a synopsis for environmental managers. Mediterr. Mar. Sci. 15, 462-473.

Piazzi, L., Cinelli, F., 2001. Distribution and dominance of two introduced turf forming macroalgae on the coast of Tuscany, Italy, northwestern Mediterranean Sea in relation to different habitats and sedimentation. Bot. Mar. 44, 509-520. 
Piazzi, L., Ceccherelli, G., Cinelli, F., 2001. Threat to macroalgal diversity: effects of the introduced green alga Caulerpa racemosa in the Mediterranean. Mar. Ecol. Prog. Ser 210, 149-159.

Piazzi, L., Meinesz, A., Verlaque, M., Akcali, B., Antolic, B., Argyrou, M., Balata, D. Ballesteros, E., Calvo, S., Cinelli, F., Cirik, S., Cossu, A., D'Archino, R., Djellouli, A., Javel, F., Lanfranco, E., Mifsud, C., Pala, D., Panayotidis, P., Peirano, A., Pergent, G. Petrocelli, A., Ruitton, S., Zuljevic, A., Ceccherelli, G., 2005. Invasion of Caulerpa racemosa var. cylindracea (Caulerpales, Chlorophyta) in the Mediterranean Sea: an assessment of the spread. Cryptogam. Algol. 26, 189-202.

Pihl, L., Isaksson, I., Wennhage, H., Moksnes, P.O., 1995. Recent increase of filamentous algae in shallow Swedish bays: effects on the community structure of epibenthic fauna and fish. Neth. J. Aquat. Ecol. 29, 349-358.

Por, F.D., 1971. One hundred years of Suez Canal - a century of Lessepsian migration: retrospect and viewpoints. Syst. Zool. 20, 138-159.

Pregnall, A.M., Rudy, P.P., 1985. Contribution of green macroalgal mats (Enteromorph spp.) to seasonal production in an estuary. Mar. Ecol. Prog. Ser. 24, 167-176.

Provan, J., 2013. The effects of past, present and future climate change on range-wide genetic diversity in northern North Atlantic marine species. Front. Biogeogr. 5 , 60-66.

Provan, J., Bennett, K.D., 2008. Phylogeographic insights into cryptic glacial refugia. Trends Ecol. Evol. 23, 564-571.

Provan, J., Wattier, R.A., Maggs, C.A., 2005. Phylogeographic analysis of the red seaweed Palmaria palmata reveals a Pleistocene marine glacial refugium in the English Channel. Mol. Ecol. 14, 793-803.

Provan, J., Booth, D., Todd, N.P., Beatty, G.E., Maggs, C.A., 2008. Tracking biological invasions in space and time: elucidating the invasive history of the green alga Codium fragile using old DNA. Divers. Distrib. 14, 343-354.

Rabalais, N.N., Turner, R.E., Diaz, R.J., Justic, D., 2009. Global change and eutrophication of coastal waters. ICES J. Mar. Sci. 66, 1528-1537.

Raven, J.A., Taylor, R., 2003. Macroalgal growth in nutrient-enriched estuaries: a biogeochemical and evolutionary perspective. Water Air Soil Pollut Focus 3, 7-26.

Raybaud, V., Beaugrand, G., Goberville, E., Delebecq, G., Destombe, C., Valero, M., Davoult, D., Morin, P., Gevaert, F., 2013. Decline in kelp in west Europe and climate. PLoS One 8, e66044.

Rayss, T., 1941. Sur les Caulerpes de la côte Palestinienne. Palest. J. Bot. Ser. II 1941, 103-124.

Reed, D.C., Brzezinski, M.A., 2009. Kelp forests. The Management of Natural Coastal Carbon Sinks. IUCN, Gland, Switzerland, p. 53 In: Laffoley, D., Grimsditch, G. (Eds.), The Management of Natural Coastal Carbon Sinks. IUCN, Gland, Switzerland, pp. 31-37.

Reise, K., 1983. Sewage, green algal mats anchored by lugworms, and the effects on Turbellaria and small Polychaeta. Helgoländer Meeresun. 36, 151-162.

Richardson, A.J., Brown, C.J., Brander, K., Bruno, J.F., Buckley, L., Burrows, M.T., Duarte, C.M., Halpern, B.S., Hoegh-Guldberg, O., Holding, J., Kappel, C.V., Kiessling, W., Moore, P.J., O'Connor, M.I., Pandolfi, J.M., Parmesan, C., Schoeman, D.S., Schwing, F., Sydeman, W.J., Poloczanska, E.S., 2012. Climate change and marine life. Biol. Lett. 8, 907-909.

Riebesell, U., Kortzinger, A., Oschlies, A., 2009. Sensitivities of marine carbon fluxes to ocean change. Proc. Natl. Acad. Sci. U. S. A. 106, 20602-20609.

Rosenberg, R., 1985. Eutrophication - the future marine coastal nuisance? Mar. Pollut. Bull. 16, 227-231.

Rueness, J., 1989. Sargassum muticum and other introduced Japanese macroalgae. Biological pollution of European coasts. Mar. Pollut. Bull. 20, 173-176.

Sabour, B., Reani, A., El Magouri, H., Haroun, R., 2013. Sargassum muticum (Yendo) Fensholt (Fucales, Phaeophyta) in Morocco, an invasive marine species new to the Atlantic coast of Africa. Aquat. Invasions 8, 97-102.

Sala, E., Boudouresque, C.F., Harmelin-Vivien, M., 1998. Fishing, trophic cascades and the structure of algal assemblages: evaluation of an old but untested paradigm. Oikos 82 , 425-439.

Sala, E., Kizilkaya, Z., Yildirim, D., Ballesteros, E., 2011. Alien marine fishes deplete algal biomass in the eastern Mediterranean. PLoS One 6, e17356.

Santiago Caamaño, J., Durán Neira, C., Acuña Castroviejo, R., 1990. Aparición de Undaria pinnatifida en las costas de Galicia (España). Un nuevo caso en la problemática de introducción de especies foráneas. Informes técnicos del Centro de Investigaciones Submarinas 3, pp. 1-45.

Saunders, G.W., Lehmkuhl, K.V., 2005. Molecular divergence and morphological diversity among four cryptic species of Plocamium (Plocamiales, Florideophyceae) in northern Europe. Eur. J. Phycol. 40, 293-312

Sauvageau, C., 1918. Sur la dissémination et la naturalisation de quelques algues marines. Bull. Inst. Océanogr. 342, 1-28.

Schaffelke, B., Hewitt, C.L., 2007. Impacts of introduced seaweeds. Bot. Mar. 50, 397-417.

Scheffers, B.R., Joppa, L.N., Pimm, S.L., Laurance, W.F., 2012. What we know and don't know about Earth's missing biodiversity. Trends Ecol. Evol. 27, 501-510.

Schiel, D.R., Foster, M.S., 1986. The structure of subtidal algal stands in temperate waters. Oceanogr. Mar. Biol. 24, 265-307.

Schmidt, A.L., Wysmyk, J.K.C., Craig, S.E., Lotze, H.K., 2012. Regional-scale effects of eutrophication on ecosystem structure and services of seagrass beds. Limnol. Oceanogr. 57, 1389-1402.

Schories, D., Albrecht, A., Lotze, H., 1997. Historical changes and inventory of macroalgae from Konigshafen Bay in the northern Wadden Sea. Helgoländer Meeresun. 51, 321-341.

Schuur, E.A.G., Vogel, J.G., Crummer, K.G., Lee, H., Sickman, J.O., Osterkamp, T.E., 2009. The effect of permafrost thaw on old carbon release and net carbon exchange from tundra. Nature 459, 556-559.

Seaman, W., 2007. Artificial habitats and the restoration of degraded marine ecosystems and fisheries. Hydrobiologia 580, 143-155.

Seys, J., Van Lent, F., Meire, P., 1991. Zeesla en bodemdieren in het Veerse Meer. Levende Nat. 92, 52-56.
Sfriso, A., Marcomini, A., 1996. Decline of Ulva growth in the lagoon of Venice. Bioresour. Technol. 58, 299-307.

Sfriso, A., Pavoni, B., Marcomini, A., Orio, A.A., 1992. Macroalgae, nutrient cycles, and pollutants in the Lagoon of Venice. Estuaries 15, 517-528.

Shi, W., Wang, M.H., 2009. Green macroalgae blooms in the Yellow Sea during the spring and summer of 2008. J. Geophys. Res. Oceans 114

Short, F.T., Burdick, D.M., Kaldy, J.E., 1995. Mesocosm experiments quantify the effects of eutrophication on eelgrass, Zostera marina. Limnol. Oceanogr. 40, 740-749.

Smale, D.A., Burrows, M.T., Moore, P., O'Connor, N., Hawkins, S.J., 2013. Threats and knowledge gaps for ecosystem services provided by kelp forests: a northeast Atlantic perspective. Ecol. Evol. 3, 4016-4038.

Smart, S.M., Thompson, K., Marrs, R.H., Le Duc, M.G., Maskell, L.C., Firbank, L.G., 2006. Biotic homogenization and changes in species diversity across human-modified ecosystems. Proc. R. Soc. B 273, 2659-2665.

Smetacek, V., Zingone, A., 2013. Green and golden seaweed tides on the rise. Nature 504, $84-88$.

Somero, G.N., 2012. The physiology of global change: linking patterns to mechanisms. Annu. Rev. Mar. Sci. 4, 39-61.

Spiller, D.A., Piovia-Scott, J., Wright, A.N., Yang, L.H., Takimoto, G., Schoener, T.W., Iwata, T., 2010. Marine subsidies have multiple effects on coastal food webs. Ecology 91, 1424-1434.

Stachowicz, J.J., Graham, M., Bracken, M.E.S., Szoboszlai, A.I., 2008. Diversity enhances cover and stability of seaweed assemblages: the role of heterogeneity and time. Ecology 89, 3008-3019.

Steneck, R.S., Graham, M.H., Bourque, B.J., Corbett, D., Erlandson, J.M., Estes, J.A., Tegner, M.J., 2002. Kelp forest ecosystems: biodiversity, stability, resilience and future. Environ. Conserv. 29, 436-459.

Stigter, T.Y., Carvalho Dill, A., Malta, E.-J., Santos, R.O.P., 2013. Nutrient sources for green macroalgae in the Ria Formosa lagoon: assessing the role of groundwater. In: Ribeiro, L., Stigter, T.Y., Chambel, A., Condesso de Melo, M.T., Monteiro, J., Medeiros, A. (Eds.), Selected Papers on Hydrogeology - Groundwater and Ecosystems. Taylor \& Francis, Leiden, The Netherlands, pp. 153-167.

Stuart-Smith, R.D., Barrett, N.S., Stevenson, D.G., Edgar, G.J., 2010. Stability in temperate reef communities over a decadal time scale despite concurrent ocean warming. Glob. Chang. Biol. 16, 122-134.

Sundbäck, K., Jönsson, B., Nilsson, P., Lindström, I., 1990. Impact of accumulating drift macroalgae on a shallow-water sediment system: an experimental study. Mar. Ecol. Prog. Ser. 58, 261-274

Susini, M.L., Mangialajo, L., Thibaut, T., Meinesz, A., 2007. Development of a transplantation technique of Cystoseira amentacea var. stricta and Cystoseira compressa. Hydrobiologia 580, 241-244.

Svensson, C.J., Pavia, H., Aberg, P., 2009. Robustness in life history of the brown seaweed Ascophyllum nodosum (Fucales, Phaeophyceae) across large scales: effects of spatially and temporally induced variability on population growth. Mar. Biol. 156, 1139-1148.

Taylor, R., Fletcher, R.L., Raven, J.A., 2001. Preliminary studies on the growth of selected 'green tide' algae in laboratory culture: effects of irradiance, temperature, salinity and nutrients on growth rate. Bot. Mar. 44, 327-336.

Teichberg, M., Fox, S.E., Olsen, Y.S., Valiela, I., Martinetto, P., Iribarne, O., Muto, E.Y., Petti, M.A.V., Corbisier, T.N., Soto-Jiménez, M., Páez-Osuna, F., Castro, P., Freitas, H., Zitelli, A., Cardinaletti, M., Tagliapietra, D., 2010. Eutrophication and macroalgal blooms in temperate and tropical coastal waters: nutrient enrichment experiments with Ulva spp. Glob. Chang. Biol. 16, 2624-2637.

Templado, J., 2014. Future trends of Mediterranean biodiversity. In: Goffredo, S., Dubinsky, Z. (Eds.), The Mediterranean Sea: Its History and Present Challenges. Springer, The Netherlands, pp. 479-498.

Thibaut, T., Meinesz, A., 2004. Caulerpa taxifolia: 18 years of infestation in the Mediterranean Sea. In: Dumont, H., Shiganova, T.A., Niermann, U. (Eds.), Aquatic Invasions in the Black, Caspian and Mediterranean Seas. Kluwer Academic Publ., pp. 287-298.

Thibaut, T., Meinesz, A., Coquillard, P., 2004. Biomass seasonality of Caulerpa taxifolia in the Mediterranean Sea. Aquat. Bot. 80, 291-297.

Thibaut, T., Pinedo, S., Torras, X., Ballesteros, E., 2005. Long-term decline of the populations of Fucales (Cystoseira, Sargassum) in the Albères coast (northwestern Mediterranean). Mar. Pollut. Bull. 50, 1472-1489.

Thibaut, T., Blanfuné, A., Markovic, L., Verlaque, M., Boudouresque, C.F., PerretBoudouresque, M., Macic, V., Bottin, L., 2014. Unexpected abundance and long-term relative stability of the brown alga Cystoseira amentacea, hitherto regarded as a threatened species, in the north-western Mediterranean Sea. Mar. Pollut. Bull. 89 (1-2), 305-323.

Thomsen, M.S., Wernberg, T., Engelen, A.H., Tuya, F., Vanderklift, M.A., Holmer, M., McGlathery, K.J., Arenas, F., Kotta, J., Sillimann, B.R., 2012. A meta-analysis of seaweed impacts on seagrasses: generalities and knowledge gaps. PLoS One 7, e28595.

Thrush, S.F., Chiantore, M., Asnaghi, V., Hewitt, J., Fiorentino, D., Cattaneo-Vietti, R., 2011. Habitat-diversity relationships in rocky shore algal turf infaunal communities. Mar. Ecol. Prog. Ser. 424, 119-132.

Thybo-Christesen, M., Rasmussen, M.B., Blackburn, T.H., 1993. Nutrient fluxes and growth of Cladophora sericea in a shallow Danish bay. Mar. Ecol. Prog. Ser. 100, 273-281.

Tilman, D. 1999. The ecological consequences of changes in biodiversity: a search for general principles. Ecology 80, 1455-1474

Titlyanov, E.A., Titlyanova, T.V., Xia, B.M., Bartsch, I., 2011. Checklist of marine benthic green algae (Chlorophyta) on Hainan, a subtropical island off the coast of China: comparisons between the 1930s and 1990-2009 reveal environmental changes. Bot. Mar. 54, 523-535.

Tournoud, M.G., Payraudeau, S., Cernesson, F., Salles, C., 2006. Origins and quantification of nitrogen inputs into a coastal lagoon: application to the Thau lagoon (France). Ecol. Model. 193, 19-33. 
Tronholm, A., Leliaert, F., Sanson, M., Afonso-Carrillo, J., Tyberghein, L., Verbruggen, H., De Clerck, O., 2012. Contrasting geographical distributions as a result of thermal tolerance and long-distance dispersal in two allegedly widespread tropical brown lgae. PLoS One 7, e30813.

Tronholm, A., Afonso-Carrillo, J., Sanson, M., Leliaert, F., Fernandez-Garcia, C., De Clerck, O. 2013. Taxonomy of the Dictyota ciliolata-crenulata complex (Dictyotales, Phaeophyceae). Phycologia 52, 171-181.

Tyler, A.C., McGlathery, K.J., Anderson, I.C., 2001. Macroalgae mediation of dissolved organic nitrogen fluxes in a temperate coastal lagoon. Estuar. Coast. Shelf Sci. 53, $155-168$.

UNEP, 2006. Marine and Coastal Ecosystems and Human Well-being: A Synthesis Report Based on the Findings of the Millenium Ecosystem Assessment. p. 76

Valentine, J.P., Magierowski, R.H., Johnson, C.R., 2007. Mechanisms of invasion: establishment, spread and persistence of introduced seaweed populations. Bot. Mar. 50, 351-360.

Valero, M., Destombe, C., Mauger, S., Ribout, C., Engel, C.R., Daguin-Thiebaut, C., Tellier, F., 2011. Using genetic tools for sustainable management of kelps: a literature review and the example of Laminaria digitata. Cah. Biol. Mar. 52, 467-483.

Valiela, I., Foreman, K., Lamontagne, M., Hersh, D., Costa, J., Peckol, P., Demeoandreson, B., Davanzo, C., Babione, M., Sham, C.H., Brawley, J., Lajtha, K., 1992. Couplings of watersheds and coastal waters: sources and consequences of nutrient enrichment in Waquoit Bay, Massachusetts. Estuaries 15, 443-457.

Valiela, I., McClelland, J., Hauxwell, J., Behr, P.J., Hersh, D., Foreman, K., 1997. Macroalgal blooms in shallow estuaries: controls and ecophysiological and ecosystem consequences. Limnol. Oceanogr. 42, 1105-1118.

Vandepitte, L., Hernandez, F., Claus, S., Vanhoorne, B., De Hauwere, N., Deneudt, K., Appeltans, W., Mees, J., 2011. Analysing the content of the European Ocean Biogeographic Information System (EurOBIS): available data, limitations, prospects and a look at the future. Hydrobiologia 667, 1-14.

Vaselli, S., Bulleri, F., Benedetti-Cecchi, L., 2008. Hard coastal-defence structures as habitats for native and exotic rocky-bottom species. Mar. Environ. Res. 66, 395-403.

Verbruggen, H., Tyberghein, L., Belton, G.S., Mineur, F., Jueterbock, A., Hoarau, G., Gurgel, C.F.D., De Clerck, O., 2013. Improving transferability of introduced species' distribution models: new tools to forecast spreading of a highly invasive seaweed. PLoS One 8.

Vergara, J.J., Sebastian, M., Perez-Llorens, J.L., Hernandez, I., 1998. Photoacclimation of Ulva rigida and $U$. rotundata (Chlorophyta) arranged in canopies. Mar. Ecol. Prog. Ser. 165, 283-292.

Verges, A., Comalada, N., Sanchez, N., Brodie, J., 2013. A reassessment of the foliose Bangiales (Rhodophyta) in the Balearic Islands including the proposed synonymy of Pyropia olivii with Pyropia koreana. Bot. Mar. 56, 229-240.

Vergés, A., Steinberg, P.D., Hay, M.E., Poore, A.G., Campbell, A.H., Ballesteros, E., Heck Jr., K.L., Booth, D.J., Coleman, M.A., Feary, D.A., Figueira, W., Langlois, T., Marzinelli, E.M., Mizerek, T., Mumby, P.J., Nakamura, Y., Roughan, M., van Sebille, E., Gupta, A.S., Smale, D.A., Tomas, F., Wernberg, T., Wilson, S.K., 2014a. The tropicalization of temperate marine ecosystems: climate-mediated changes in herbivory and community phase shifts. Proc. R. Soc. B 281, 20140846.

Vergés, A., Tomas, F., Cebrian, E., Ballesteros, E., Kizilkaya, Z., Dendrinos, P., Karamanlidis, A., Spiegel, D., Sala, E., 2014b. Tropical rabbitfish and the deforestation of a warming temperate sea. J. Ecol. 102, 1518-1527.

Verlaque, M., 1990. Relations entre Sarpa salpa (Linnaeus, 1758) (Téléostéen, Sparidae), les autres poissons brouteurs et le phytobenthos algal méditerranéen. Oceanol. Acta $13,373-388$

Verlaque, M., 2001. Checklist of the macroalgae of Thau Lagoon (Herault, France), a hot spot of marine species introduction in Europe. Oceanol. Acta 24, 29-49.

Verlaque, M., Boudouresque, C.F., 1991. Stypopodium schimperi (Buchinger ex Kützing) Verlaque et Boudouresque comb. nov. (Dictyotales, Fucophyceaea), algue de Mer Rouge récemment apparue en Méditerranée. Cryptogam. Algol. 10, 313-323.
Verlaque, M., Durand, C., Huisman, J.M., Boudouresque, C.F., Le Parco, Y., 2003. On the identity and origin of the Mediterranean invasive Caulerpla racemosa (Caulerpales, Chlorophyta). Eur. J. Phycol. 38, 325-339.

Verlaque, M., Brannock, P.M., Komatsu, T., Villalard-Bohnsack, M., Marston, M., 2005. The genus Grateloupia C. Agardh (Halymeniaceae, Rhodophyta) in the Thau Lagoon (France, Mediterranean): a case study of marine plurispecific introductions. Phycologia 44, 477-496.

Verlaque, M., Steen, F., De Clerck, O., 2009. Rugulopteryx (Dictyotales, Phaeophyceae), a genus recently introduced to the Mediterranean. Phycologia 48, 536-542.

Vermeij, G.J., 2012. The tropical history and future of the Mediterranean biota and the West African enigma. J. Biogeogr. 39, 31-41.

Viejo, R.M., Martinez, B., Arrontes, J., Astudillo, C., Hernandez, L., 2011. Reproductive patterns in central and marginal populations of a large brown seaweed: drastic changes at the southern range limit. Ecography 34, 75-84.

Viscusi, G., 2011. 'Green tides' drive away Brittany tourists. Bloomberg (3 August 2011 http://www.bloomberg.com/news/2011-08-03/brittany-green-tides-drive-awaytourists-from-french-beaches.html).

Walker, D.I., Kendrick, G.A., 1998. Threats to macroalgal diversity: marine habitat destruction and fragmentation, pollution and introduced species. Bot. Mar. 41, 105-112.

Wennhage, H., Pihl, L., 2007. From flatfish to sticklebacks: assemblage structure of epibenthic fauna in relation to macroalgal blooms. Mar. Ecol. Prog. Ser. 335, 187-198.

Wernberg, T., Russell, B.D., Moore, P.J., Ling, S.D., Smale, D.A., Campbell, A., Coleman, M.A. Steinberg, P.D., Kendrick, G.A., Connell, S.D., 2011a. Impacts of climate change in a global hotspot for temperate marine biodiversity and ocean warming. J. Exp. Mar. Biol. Ecol. 400, 7-16.

Wernberg, T., Russell, B.D., Thomsen, M.S., Gurgel, C.F.D., Bradshaw, C.J.A., Poloczanska, E.S., Connell, S.D., 2011b. Seaweed communities in retreat from ocean warming Curr. Biol. 21, 1828-1832.

Wernberg, T., Thomsen, M.S., Tuya, F., Kendrick, G.A., Staehr, P.A., Toohey, B.D., 2010. Decreasing resilience of kelp beds along a latitudinal temperature gradient: potential implications for a warmer future. Ecol. Lett. 13, 685-694.

Wilcove, D.S., Rothstein, D., Dubow, J., Phillips, A., Losos, E., 1998. Quantifying threats to imperiled species in the United States. Bioscience 48, 607-615.

Wilkinson, M., Wood, P., Wells, E., Scanlan, C., 2007. Using attached macroalgae to assess ecological status of British estuaries for the European Water Framework Directive. Mar. Pollut. Bull. 55, 136-150.

Williams, S.L., Smith, J.E., 2007. A global review of the distribution, taxonomy, and impacts of introduced seaweeds. Annu. Rev. Ecol. Evol. Syst. 38, 327-359.

Withers, R.G., Farnham, W.F., Lewey, S., Jephson, N.A., Haythorn, J.M., Gray, P.W.G., 1975 Epibionts of Sargassum muticum in British waters. Mar. Biol. 31, 79-86.

Wolf, M.A., Sfriso, A., Andreoli, C., Moro, I., 2011. The presence of exotic Hypnea flexicaulis (Rhodophyta) in the Mediterranean Sea as indicated by morphology, rbcL and cox 1 analyses. Aquat. Bot. 95, 55-58.

Worm, B., Barbier, E.B., Beaumont, N., Duffy, J.E., Folke, C., Halpern, B.S., Jackson, J.B.C. Lotze, H.K., Micheli, F., Palumbi, S.R., Sala, E., Selkoe, K.A., Stachowicz, J.J., Watson, R., 2006. Impacts of biodiversity loss on ocean ecosystem services. Science 314, 787-790.

Wynne, M.J., 2006. Portraits of Marine Algae: An Historical Perspective. The University of Michigan Herbarium, Ann Arbor, Michigan.

Yoshida, T., 1998. Marine Algae of Japan. Uchida Rokakuho Publishing Co. Ltd., Tokyo.

Zardi, G.I., Nicastro, K.R., Canovas, F., Costa, J.F., Serrao, E.A., Pearson, G.A. 2011. Adaptive traits are maintained on steep selective gradients despite gene flow and hybridization in the intertidal zone. PLoS One 6, e19402.

Zhang, X.W., Xu, D., Mao, Y.Z., Li, Y.X., Xue, S.Y., Zou, J., Lian, W., Liang, C.W., Zhuang, Z.M. Wang, Q.Y., Ye, N.H., 2011. Settlement of vegetative fragments of Ulva prolifera confirmed as an important seed source for succession of a large-scale green tide bloom. Limnol. Oceanogr. 56, 233-242. 